\title{
A Framework to Explore the Functioning ANd Sustainability OF Business Models
}

Authors: Peter Bradley ${ }^{a}$, Glenn Parry ${ }^{b}$ and Nicholas O'Regan ${ }^{c}$

a Department for Accounting, Economics and Finance, University of the West of England, Frenchay Campus, Coldharbour Lane, Bristol, UK, BS16 1QY.

b Department of Digital Economy, Entrepreneurship and Innovation, University of Surrey, Guildford, Surrey, GU27XH.

${ }^{c}$ Department for Marketing and Strategy, Aston University, Birmingham, B4 7ET.

Emails: Peter.Bradley@uwe.ac.uk; G.Parry@surrey.ac.uk; N.Oregan@aston.ac.uk

Corresponding author: Peter Bradley

Key words: Value; Business model; Sustainable development; Sustainability; Value maximising; societal value 


\section{Highlights}

- Conceptualisation of value is key to sustainable business model innovation

- Equity and distributional impacts are key in business models sustainability

- Sustainability of the business model is explored;

- Economies of scope are critical to this case study's business model 


\title{
A FramewOrk to Explore the FunCtioning AND SUSTAINABILITY OF
}

\section{BUSINESS Models}

\begin{abstract}
This paper presents a framework to enable case study analysis of sustainable development from business models innovation. Increasing economic development can give rise to tradeoffs between economic growth and environmental degradation. Business model innovation can help address such trade-offs by refocusing value creation and capture towards less environmentally damaging activities. Business models therefore provide a critical tool in the move towards sustainable development. In this paper a literature review of existing business model frameworks is conducted and gaps found in the definition and conceptualisation of value, alignment with sustainable development, and assessment of social and environmental impacts and goals. More generally, there is a lack of in depth case studies in the sustainable business model literature. A framework is developed to address these gaps and to allow in depth analysis and understanding of the functioning of business models for sustainable development. Development and piloting of the framework made use of literature and co-operative enquiry. The framework of the paper is applied in depth with a unique energy company case study. Application shows economies of scope to be critical to the delivery of sustainable development. The business model framework addresses equity and distributional issues that are key to sustainable development, but missed by current frameworks.
\end{abstract}

Key words: Value; Business model; Sustainable development; Sustainability; Value maximising. 


\section{Introduction}

The scale of resource use to supply consumer goods and services is the main reason that society stands so close to breaching many boundaries set out for key global environmental pressures (Allwood 2011; Rockström et al 2009). Many managers are aware of the increasing importance of being socially and environmentally sustainable in their operations. More sustainable goods and services provision requires a combination of new technologies, changes in practice/behaviours, in combination with new business models. To make such a change it is helpful for organisations to be able to observe past case studies. Evan et al (2017) however identify a scarce number of case studies and empirical analysis of sustainable business models in the literature and that the lack of case studies makes it difficult for firms to learn how they might develop their business models. From literature they also find that existing business modelling methods and tools are few and rarely sustainability driven. The current papers objective is to develop a framework for in depth case study analysis of business models for sustainability. The framework builds on Osterwalder and Pigneur (2010) as well as Evans et al (2017) among others. An in depth case study analysis is then presented to demonstrate the framework and provide new case study empirical analysis that is much required. Business model frameworks for sustainability need to identify profit centres, and help unpick the full range of other value that a business model is able to create and capture and for whom, as such an exploration is key to understanding the organisations sustainable development contribution. Application of the framework demonstrates the framework's capabilities and provides new empirical case study analysis.

The research questions of the study are: 
1. Can a business model framework be developed that can address gaps in conceptualisation, definition and measurement of value, and sustainable development?

2. Does the framework lead to in depth understanding of the functioning of the business model for sustainable development?

The structure of the paper is as follows: This paper starts by conducting a literature review of existing business model frameworks for sustainable development and their strengths and weaknesses in addressing value (in different forms) and sustainable development (Section 1). The method is then outlined (section 2). Following on from this the paper presents an alternative framework (with case study results) that extends Osterwalder and Pigneur (2010) to make fit for understanding sustainable development (section 3). Results from the application of the framework to a case study of an energy company with a keen focus on sustainability demonstrates the framework's capabilities in understanding and assessing sustainable development and functioning of the business model. Discussions and conclusions are then drawn in section 4 .

\section{Background to developing the framework}

Our Common Future (WCED 1987) also known as the Brundtland Report was the watershed publication in terms of transforming societies thinking on environment, development and governance. Sustainable development has been defined in many ways in the literature (see for example Mebratu 1998 and Pezzoli 1997) and there is substantial disagreement, differences in argument and opinion concerning how it should be defined, see for example Lele (1991), Beckerman (1994), Robinson (1997), Sneddon et al. (2006), DesJardins (2015) and Pater and Cristea (2016). The Brundtland definition of sustainable development is currently the most 
widely accepted starting point for scholars and practitioners focused on environment and development dilemmas: "development that meets the needs of the present without compromising the ability of future generations to meet their own needs" (WCED 1987).

Aligned with the Brundtland definition, the three main aims of sustainable development are: 1 . Economic aim: improved equity in resource distribution across and within societies; 2. Social aim: improving human well-being; and 3. Environmental aim: development that stays within environmental constraints and maintains ecological integrity over intergenerational timescales (Sneddon et al 2006).

A core set of papers are reviewed from the sustainable business model literature. The literature was searched by key words such as sustainable business models, papers were then collated. An additional check of important papers was picked up through consultation with the research team. The author then established whether papers provided frameworks for understanding and designing business models for sustainable development, if they did then these were reviewed. In terms of method of assessment of studies included for review, relevant papers were assessed by researchers in terms their strengths and weaknesses for: 1.) addressing sustainable development; and 2.) understanding, defining and conceptualisation of value. 3.) Applicability in detailed case study analysis in the current study. Applicability in detailed case study analysis was assessed by seeing the extent to which each framework would allow the analyst to pick up on the range of elements important to understanding a business model in depth and its sustainability. This is why we have the criterion applicability in detailed case study analysis in the far-right hand column of the table." 
Table 1: Assessing frameworks from the sustainable business models' literature for application in the current study

\begin{tabular}{|c|c|c|c|c|}
\hline & Aim and Contribution & $\begin{array}{l}\text { Main 'Strengths' of framework in addressing } \\
\text { 'sustainable development' and conceptualising } \\
\text { and identifying 'value'. }\end{array}$ & $\begin{array}{l}\text { Main 'Weaknesses' of framework in } \\
\text { addressing 'sustainable development' and } \\
\text { conceptualising and identifying 'value'. }\end{array}$ & \begin{tabular}{|c|} 
Applicability \\
for detailed \\
case study \\
business \\
model analysis
\end{tabular} \\
\hline 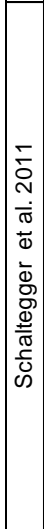 & $\begin{array}{l}\text { - Proposes a framework } \\
\text { for business model } \\
\text { innovation } \\
\text {-Identifies how } \\
\text { sustainability strategy is } \\
\text { combined with business } \\
\text { model innovation } \\
\text { - Identifies the } \\
\text { interrelations between } \\
\text { business models and } \\
\text { business case drivers. }\end{array}$ & $\begin{array}{l}\text { - Shows how different sustainability strategies lead } \\
\text { to business success and how each business case } \\
\text { contributes; } • \text { The connection between sustainability } \\
\text { strategy and business case impact is made; } \bullet \text { The } \\
\text { framework is good and useful in assessing which } \\
\text { types of business model innovation for sustainability } \\
\text { tend to lead to greater business cases; } \cdot \text { The paper } \\
\text { identifies a very useful range of core drivers of } \\
\text { business cases for sustainability such as cost } \\
\text { reduction; risk and risk reduction; attractiveness as } \\
\text { employer etc. • The paper mentions that key to } \\
\text { business models for sustainability is to create } \\
\text { customer and social value by integrating social, } \\
\text { environmental and business activities; } \\
\text { framework provides a useful typology of } \\
\text { sustainability oriented business model innovation; } \\
\text { Environmental, social and economic impacts are } \\
\text { discussed. }\end{array}$ & $\begin{array}{l}\text { - No definition of sustainable development is } \\
\text { provided. The paper discusses reducing resource } \\
\text { use and social and environmental performance } \\
\text { etc., there is no mention of equity in resource } \\
\text { distribution or wellbeing etc. • A list of social and } \\
\text { environmental measures is not provided; } \cdot \text { Value is } \\
\text { not defined or conceptualised. From reading, value } \\
\text { is predominantly discussed and seen through the } \\
\text { lens of the business case for sustainability, i.e. } \\
\text { positive economic effect from social and } \\
\text { environmental and management activities to } \\
\text { improve sustainability. The predominant focus } \\
\text { from this language is focused on value for the firm } \\
\text { from implementing sustainability. This seems to be } \\
\text { seen as the key means to achieving sustainability, } \\
\text { i.e. through creating a business case for it. }\end{array}$ & $\begin{array}{l}\text { - The framework } \\
\text { is not intended } \\
\text { to be used in } \\
\text { detailed design } \\
\text { of a firm's } \\
\text { business model } \\
\text { for sustainability; } \\
\text { but in identifying } \\
\text { general patterns } \\
\text { in relation to } \\
\text { strategies and } \\
\text { business cases; }\end{array}$ \\
\hline 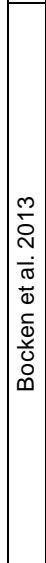 & $\begin{array}{l}\text { - Value mapping tool to } \\
\text { develop value } \\
\text { propositions } \\
\text { - Multiple stakeholder } \\
\text { view of value } \\
\text {-Network centric (Zott } \\
\text { and Amit 2010) } \\
\text { - Includes concepts of } \\
\text { value destroyed/ wasted/ } \\
\text { missed, and } \\
\text { opportunities for value } \\
\text { creation. }\end{array}$ & $\begin{array}{l}\cdot \text { The broad Brundtland definition of sustainable } \\
\text { development is defined, although the framework is } \\
\text { not systematically connected to the definition and no } \\
\text { detailed aims for sustainable development are set } \\
\text { out; } • \text { Helps firms rethink the positive and negative } \\
\text { value created for stakeholders; } • \text { The terms social, } \\
\text { environmental and economic value are used but not } \\
\text { defined and also talk about value destroyed/ } \\
\text { wasted/ missed, value opportunities and capture; } \\
\cdot \text { The tool helps individuals recognise opportunities } \\
\text { for new value creation; value missed and what they } \\
\text { term value destroyed; } \cdot \text { The tool can help identify } \\
\text { conflicting values and potential opportunities for } \\
\text { business model re-design; } \bullet \text { The value innovation } \\
\text { diagram and value mapping tool could be applied in } \\
\text { tandem with a more detailed framework; } \cdot \text { Helps } \\
\text { identify priorities for areas to evolve for greatest } \\
\text { impact on value • Environmental, social and } \\
\text { economic impacts discussed. }\end{array}$ & $\begin{array}{l}\text { - The tool discusses reducing resource use, social } \\
\text { and environmental impacts but there is no mention } \\
\text { of equity in resource distribution, } 1 \text { st aim of } \\
\text { sustainable development; } \bullet \text { There is no definition of } \\
\text { value only some examples of value destroyed/ } \\
\text { wasted/ missed; } \cdot \text { Measures of social and } \\
\text { environmental impacts and indicators are not } \\
\text { provided } \cdot \text { Limitations in conceptualisation of value; } \\
\text { value cannot be destroyed if perceived; }\end{array}$ & $\begin{array}{l}\cdot \text { Does not take } \\
\text { one through } \\
\text { looking the } \\
\text { range of } \\
\text { components of } \\
\text { the business } \\
\text { model; } \cdot \text { The tool } \\
\text { is said to be just } \\
\text { one step in a } \\
\text { business } \\
\text { modelling } \\
\text { process, further } \\
\text { work is said to } \\
\text { be required to } \\
\text { develop a } \\
\text { complete toolset } \\
\text { and process. }\end{array}$ \\
\hline & $\begin{array}{l}\text { - Detailed review of the } \\
\text { literature \& development } \\
\text { of } 8 \text { different sustainable } \\
\text { business model } \\
\text { archetypes }\end{array}$ & $\begin{array}{l}\cdot \text { Methods of developing sustainability archetypes } \\
\text { are rigorous; } \bullet \text { Resulting classifications/ archetypes } \\
\text { are applicable to the community researching; } \\
\cdot \text { Examples for each archetype are provided; } \\
\cdot \text { Authors examine value proposition, value creation, } \\
\text { delivery, and capture; } \bullet \text { Mentions social, economic } \\
\text { and environmental value and the importance of } \\
\text { creating and capturing these types of value in } \\
\text { sustainable business models; } \cdot \text { Develops and } \\
\text { communicates a useful language for classifying } \\
\text { sustainable business model types } \cdot \text { Environmental, } \\
\text { social and economic impacts are discussed }\end{array}$ & $\begin{array}{l}\cdot \text { Sustainable development is not defined, nor its } \\
\text { aims and measures for assessing social and } \\
\text { environmental aspects are not provided; } \bullet \text { Value is } \\
\text { not defined; } \bullet \text { The approach is reflective drawing on } \\
\text { past literature (also a strength) so relies on } \\
\text { secondary data; } \bullet \text { Only three business model } \\
\text { categories are examined - value proposition, } \\
\text { creation and capture, this therefore limits the use } \\
\text { for detailed sustainable business model case study } \\
\text { analysis. }\end{array}$ & $\begin{array}{l}\text { - The framework } \\
\text { is not detailed } \\
\text { enough to allow } \\
\text { one to assess } \\
\text { the range of key } \\
\text { components of } \\
\text { the business } \\
\text { model for } \\
\text { sustainability }\end{array}$ \\
\hline 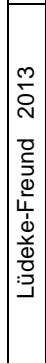 & $\begin{array}{l}\text { Framework to support } \\
\text { and systematically } \\
\text { structure research on } \\
\text { sustainable } \\
\text { entrepreneurship with an } \\
\text { innovation and business } \\
\text { model focus } \\
\text { - Framework has generic } \\
\text { quality with vertical and } \\
\text { horizontal structured } \\
\text { relationships between } \\
\text { different concepts }\end{array}$ & $\begin{array}{l}\cdot \text { The framework recognises the relationships } \\
\text { between sustainability innovation, business model } \\
\text { and business case; } \bullet \text { The study brings out the } \\
\text { importance of the business case for sustainability; } \bullet \\
\text { Identifies policy and financing influence on the } \\
\text { sustainable business model and business case; } \\
\text { Identifies key relationships and interfaces; } \bullet \\
\text { Identifies most important barriers to sustainable } \\
\text { entrepreneurs and their business models; } \cdot \text { The } \\
\text { framework mentions, social, ecological and } \\
\text { economic value; • Environmental, social and } \\
\text { economic impacts are discussed. }\end{array}$ & $\begin{array}{l}\cdot \text { Sustainable development and sustainability and } \\
\text { aims are not defined; } \cdot \text { Environmental and social } \\
\text { indicators/measures not provided; } \bullet \text { Value is not } \\
\text { defined and conceptualised in depth; }\end{array}$ & $\begin{array}{l}\text { - The framework } \\
\text { is not detailed } \\
\text { enough to allow } \\
\text { one to assess } \\
\text { the range of key } \\
\text { components of } \\
\text { the business } \\
\text { model for } \\
\text { sustainability; }\end{array}$ \\
\hline
\end{tabular}




\begin{tabular}{|c|c|c|c|c|}
\hline & Aim and Contribution & $\begin{array}{l}\text { Main 'Strengths' of framework in addressing } \\
\text { 'sustainable development' and conceptualising } \\
\text { and identifying 'value'. }\end{array}$ & $\begin{array}{l}\text { Main 'Weaknesses' of framework in } \\
\text { addressing 'sustainable development' and } \\
\text { conceptualising and identifying 'value'. }\end{array}$ & \begin{tabular}{|} 
Applicability \\
for detailed \\
case study \\
business \\
model analysis \\
in current
\end{tabular} \\
\hline & $\begin{array}{l}\text { - Comprehensive } \\
\text { overview of the business } \\
\text { model innovation } \\
\text { process and different } \\
\text { steps through the } \\
\text { proposed framework }\end{array}$ & $\begin{array}{l}\text { - The framework outlines potential steps for } \\
\text { implementing business model innovation for } \\
\text { sustainability; } \bullet \text { Relevant for identification/integration } \\
\text { of new and existing tools into a structured and } \\
\text { synergistic portfolio } \bullet \text { Environmental, social and } \\
\text { economic impacts are discussed. }\end{array}$ & $\begin{array}{l}\cdot \text { Sustainable development and value are not } \\
\text { defined; } \bullet \text { Detailed social and environmental } \\
\text { indicators are not provided; }\end{array}$ & $\begin{array}{l}- \text { Framework } \\
\text { does not provide } \\
\text { detailed } \\
\text { understanding of } \\
\text { the functioning } \\
\text { of the different } \\
\text { parts of the } \\
\text { business model }\end{array}$ \\
\hline & $\begin{array}{l}\text { - First attempt to } \\
\text { integrate design thinking } \\
\text { into sustainable business } \\
\text { model innovation } \\
\text { - A process for } \\
\text { developing workshop } \\
\text { framework-based } \\
\text { management tools was } \\
\text { developed }\end{array}$ & $\begin{array}{l}\cdot \text { A new workshop framework is developed to help } \\
\text { develop sustainable business models based on } \\
\text { value mapping processes, developed by literature } \\
\text { synesis, expert interviews and multiple workshops. } \\
\cdot \text { Helps look at value ideas and value opportunity } \\
\text { selection and value proposition prototyping; } \bullet \text { helps } \\
\text { to create additional forms of value for business, the } \\
\text { value mapping tool is applied in the paper (therefore } \\
\text { looks at missed value, value destroyed etc.); } \cdot \text { The } \\
\text { paper mentions economic, societal and } \\
\text { environmental value and wider range of stakeholder } \\
\text { interest; • Applies a network centric perspective on } \\
\text { value (as opposed to firm level); } \cdot \text { Workshop } \\
\text { process/steps are provided; } \cdot \text { Design thinking was } \\
\text { found to be a useful approach with value mapping. }\end{array}$ & $\begin{array}{l}\cdot \text { Sustainable development and its aims are not } \\
\text { defined and aligned; } \cdot \text { Environmental and social } \\
\text { indicators/measures are not provided; } \bullet \text { Value is not } \\
\text { defined, they apply the value approach of Bocken } \\
\text { et al (2013); }\end{array}$ & $\begin{array}{l}\text { The framework } \\
\text { does not provide } \\
\text { detailed } \\
\text { understanding of } \\
\text { the functioning } \\
\text { of the different } \\
\text { parts of the } \\
\text { business model; }\end{array}$ \\
\hline & $\begin{array}{l}- \text { Explores the } \\
\text { contributions and } \\
\text { limitations of an } \\
\text { integrative performance } \\
\text { measurement framework } \\
\text { for sustainable business } \\
\text { models }\end{array}$ & $\begin{array}{l}\text { - Performance measurement includes stakeholder } \\
\text { satisfaction; strategic drivers, business processes, } \\
\text { capabilities/stakeholder contribution • Sustainability } \\
\text { is assessed using existing data in the Dow Jones } \\
\text { Sustainability Index available for some large } \\
\text { companies • Environmental, social and economic } \\
\text { impacts are discussed; } \cdot \text { Framework uses the } \\
\text { terms sustainable value but does not define. }\end{array}$ & $\begin{array}{l}\cdot \text { Sustainability or sustainable development is not } \\
\text { defined nor its aims; } \cdot \text { Sustainability is assessed } \\
\text { using existing secondary data in the Dow Jones } \\
\text { Sustainability Index, data is only available for some } \\
\text { larger companies here; } \bullet \text { The framework makes } \\
\text { use of secondary data for case studies, inhibits } \\
\text { ability to reveal a company's true strategy /business } \\
\text { model } \cdot \text { Value is not defined }\end{array}$ & $\begin{array}{l}\text { - The framework } \\
\text { is not detailed } \\
\text { enough to allow } \\
\text { one to assess } \\
\text { the range of key } \\
\text { components of } \\
\text { the business } \\
\text { model for } \\
\text { sustainability; }\end{array}$ \\
\hline & $\begin{array}{l}\text { - Aims expand } \\
\text { knowledge of the } \\
\text { relationship between } \\
\text { sustainable product } \\
\text { procurement and } \\
\text { sustainable business } \\
\text { models }\end{array}$ & $\begin{array}{l}\cdot \text { The framework links sustainable product } \\
\text { procurement concept with sustainable business } \\
\text { models concept; } \cdot \text { The paper looks at how } \\
\text { sustainable procurement leads to more sustainable } \\
\text { business models; } \bullet \text { Shifts focus from price per unit } \\
\text { to value per service } \bullet \text { Closes loops, reducing raw } \\
\text { materials and waste }- \text { focus on circular economy } \\
\text { which has limitations in addressing sustainability on } \\
\text { its own; } \cdot \text { Aligns specifications/ understanding of } \\
\text { possibilities and challenges and can help } \\
\text { collaboration and conflict resolution }\end{array}$ & $\begin{array}{l}\cdot \text { A definition of sustainable development and aims } \\
\text { are not provided; } \cdot \text { Focus on circular economy } \\
\text { concept has some limitations in addressing } \\
\text { sustainability; } \bullet \text { Environmental indicators or } \\
\text { measures are not provided; } \cdot \text { The value } \\
\text { discussions mainly focus on conventional terms } \\
\text { and discussion, excluding interesting discussions } \\
\text { and focus on value per service } \cdot \text { Value itself is not } \\
\text { defined }\end{array}$ & $\begin{array}{l}\text { - The framework } \\
\text { is not focused } \\
\text { on assessing the } \\
\text { range of key } \\
\text { components of } \\
\text { the business } \\
\text { model for } \\
\text { sustainability; }\end{array}$ \\
\hline 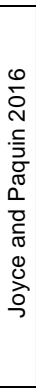 & $\begin{array}{l}\text { - Environmental and } \\
\text { social business model } \\
\text { canvas as direct } \\
\text { extensions of } \\
\text { Osterwalder and Pigneur } \\
(2010) \text { as a practical } \\
\text { tool }\end{array}$ & $\begin{array}{l}\cdot \text { First publication extending Osterwalder and } \\
\text { Pigneur }(2010) \text { canvas to include environmental and } \\
\text { social aspects; • A triple layer, business, social and } \\
\text { environmental model aids assessment of } \\
\text { sustainability; } • \text { An advantage is said to be that each } \\
\text { layer has similar categories and can be considered } \\
\text { in light of the others; • Deals with different } \\
\text { stakeholders and is relatively easy to apply; } \\
\text { Suitable for case study analysis of sustainability; } \\
\text { This is a detailed framework so can help in } \\
\text { understanding a business model for sustainability in } \\
\text { depth } \cdot \text { Environmental, social and economic impacts } \\
\text { are discussed }\end{array}$ & $\begin{array}{l}\cdot \text { A definition of sustainable development and aims } \\
\text { are not provided; } \bullet \text { Lacks alignment between goals, } \\
\text { framework and outcomes; } \bullet \text { Information is not given } \\
\text { on how the three canvases interact; } \bullet \text { The three } \\
\text { canvases are done/seen separately and focus is on } \\
\text { the firm (firm centric); } \bullet \text { Questions for categories } \\
\text { are not provided; } \bullet \text { Definition and conceptualisation } \\
\text { of value is not provided } \bullet \text { Application uses } \\
\text { secondary data; } \bullet \text { could have more key indicators } \\
\text { and be more strategic in approaching sustainable } \\
\text { development. }\end{array}$ & \begin{tabular}{|l|} 
Potential \\
applicable but \\
has some \\
weakenesses as \\
identified.
\end{tabular} \\
\hline & $\begin{array}{l}\text { - Presents a } \\
\text { framework(first } \\
\text { developed in an MSc by } \\
\text { Upward 2013) for } \\
\text { assessing sustainability } \\
\text { of business models } \\
\text { - Framework is detailed } \\
\text { and can be applied to } \\
\text { examine a firms design } \\
\text { for sustainability }\end{array}$ & $\begin{array}{l}\text { - One of the only studies to define value (defined as } \\
\text { 'goodness' and also in terms of satisfying needs); } \\
\text { Detailed framework for understanding a business } \\
\text { model for sustainability and plenty of background } \\
\text { provided; } \bullet \text { Attempts to define a sustainable firm; } \bullet \\
\text { Environmental, social and economic impacts } \\
\text { discussed. - The authors bring out some interesting } \\
\text { discussions relating to value, which is a usefull } \\
\text { contribution. }\end{array}$ & $\begin{array}{l}\text { The 1st aim of sustainable development is not } \\
\text { addressed; } \bullet \text { The term value destroyed }- \text { value } \\
\text { cannot be destroyed if perceived; } \bullet \text { Discussion of } \\
\text { value has very limited conceptualisation; } • \text { Tri profit } \\
\text { is not suitable for looking at value for the range of } \\
\text { stakeholders relevant to sustainable development; } \\
\text { - Metrics measuring environmental, social and } \\
\text { economic are not fully provided. • The framework } \\
\text { lacks alignment between definitions, goals, } \\
\text { framework focus and outcomes for sustainability; }\end{array}$ & \begin{tabular}{|l|} 
Potential \\
applicable but \\
has some \\
weakenesses as \\
identified. \\
- Application of \\
the framework is \\
resource \\
intensive and \\
difficult for firms \\
to implement. \\
\end{tabular} \\
\hline
\end{tabular}




\begin{tabular}{|c|c|c|c|c|}
\hline & Aim and Contribution & $\begin{array}{l}\text { Main 'Strengths' of framework in addressing } \\
\text { 'sustainable development' and conceptualising } \\
\text { and identifying 'value'. }\end{array}$ & $\begin{array}{l}\text { Main 'Weaknesses' of framework in } \\
\text { addressing 'sustainable development' and } \\
\text { conceptualising and identifying 'value'. }\end{array}$ & \begin{tabular}{|c|} 
Applicability \\
for detailed \\
case study \\
business \\
model analysis
\end{tabular} \\
\hline 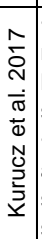 & $\begin{array}{l}\text { - Develops a conceptual } \\
\text { model of relationship } \\
\text { leadership for strategic } \\
\text { sustainability in practice } \\
\text {-Describes practices } \\
\text { and capabilities to } \\
\text { support a framework for } \\
\text { strategic sustainable }\end{array}$ & $\begin{array}{l}\text { - Introduces leadership into sustainable business } \\
\text { models; } \cdot \text { Environmental, social and economic } \\
\text { impacts discussed } \cdot \text { The framework by Upward and } \\
\text { Jones }(2016) \text { is used in the study provided in the } \\
\text { Appendix. So comments applying to their paper } \\
\text { apply here. } \cdot \text { Mentions economic, social and natural } \\
\text { value and needs are discussed. } \cdot \text { The framework is } \\
\text { provided in the appendix. }\end{array}$ & $\begin{array}{l}\text { - Value and sustainable development are not } \\
\text { defined; }\end{array}$ & $\begin{array}{l}\text { - The framework } \\
\text { is not focused } \\
\text { on assessing the } \\
\text { range of key } \\
\text { components of } \\
\text { the business } \\
\text { model for } \\
\text { sustainability; }\end{array}$ \\
\hline 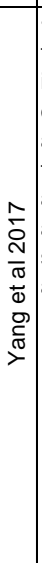 & $\begin{array}{l}\text { - Paper describes a tool } \\
\text { that can help companies } \\
\text { identify new } \\
\text { opportunities to create } \\
\text { and capture value } \\
\text { through sustainability by } \\
\text { analysing value captured } \\
\text { and uncaptured for key } \\
\text { stakeholders. A lifecycle } \\
\text { approach is explored. }\end{array}$ & $\begin{array}{l}\cdot \text { Tool provides a broader way of looking at new } \\
\text { value opportunities that allows value related to } \\
\text { sustainability to be realised and captured. Defines } \\
\text { and applies a concept of value uncaptured, usefull } \\
\text { for understanding new opportunities for creating and } \\
\text { capturing value accross stakeholders, using a life } \\
\text { cycle perspective. • Attempts to take full life cycle } \\
\text { approach, important to sustainability. } \cdot \text { Looks at } \\
\text { economic, social and environmental value and value } \\
\text { uncaptured; } \cdot \text { Accounts for multiple stakeholders; } \cdot \\
\text { Good process to capture data; } \cdot \text { Creative approach } \\
\text { using cards; }\end{array}$ & $\begin{array}{l}\cdot \text { Does not look at the dimensions of the business } \\
\text { model and their interconnection - only focused on } \\
\text { one element, value; • Does not allow one to } \\
\text { understand how different elements of the business } \\
\text { model interact and work together to create and } \\
\text { capture value; } \cdot \text { Tool not designed to explore } \\
\text { interaction of context and value; } \cdot \text { Does not provide } \\
\text { in-depth understanding on the case study business } \\
\text { model (as not designed for) and exactly how the } \\
\text { business model elements interact to create and } \\
\text { capture value - therefore limited for in-depth case } \\
\text { study analysis of existing business models and } \\
\text { exactly how they create and capture value; } \\
\text { Definitions of value are not provided beyond the } \\
\text { concept of value uncaptured; • Definitions of } \\
\text { sustainability or sustainable development not } \\
\text { provided; } \cdot \text { No indicators for social and } \\
\text { environmental value provided; } \cdot \text { Limited detail } \\
\text { provided on results from sustainability case }\end{array}$ & $\begin{array}{l}\text { - The framework } \\
\text { is not focused } \\
\text { on assessing the } \\
\text { range of key } \\
\text { components of } \\
\text { the business } \\
\text { model for } \\
\text { sustainability; } \\
\text { and how they } \\
\text { interact to create } \\
\text { and capture } \\
\text { value. }\end{array}$ \\
\hline & \begin{tabular}{|l|} 
Attempts to \\
systematically integrate \\
corporate sustainability \\
principles (including \\
economic, environmental \\
and social goals; multi- \\
stakeholder perspective \\
and long term outlook) \\
into core business.
\end{tabular} & $\begin{array}{l}\text { - Uses sustainable development goals (SDGs) to } \\
\text { help assess sustainability/what SDG challenges are } \\
\text { core to the company - the framework provides a } \\
\text { brief discussion of SDGs and examples of } \\
\text { sustainable business models and then asks what } \\
\text { are the main contributions to SDGs? • Uses the } \\
\text { value mapping tool first developed by Bocken et al } \\
2013 ; \cdot \text { Asks what sustinable value do firms } \\
\text { stakeholders capture? • The framework uses eight } \\
\text { questions to explore the business model - fairly } \\
\text { straightforward to apply; • The tool provides } \\
\text { reflections about organisations reasons for } \\
\text { existence and deployment of this purpose into the } \\
\text { business model dimensions from a multi- } \\
\text { stakeholder and from a value exchange perspective. } \\
\text { • Considers context generally like Upward and } \\
\text { Jones } 2016 ; \cdot \text { Acknowledges that with the tool there } \\
\text { is not well defined thresholds to delimit if a business } \\
\text { model is sustainable or not. }\end{array}$ & $\begin{array}{l}\text { - In the paper it is said that the tool allows an } \\
\text { overview of the business model, but there is not } \\
\text { evidence from the results that the tool enables in } \\
\text { depth case study analysis of the business model } \\
\text { and its functioning; } \cdot \text { Limited detail provided of } \\
\text { results from case studies. • Paper does not define } \\
\text { value and its different forms; } \cdot \text { Paper does not } \\
\text { define sustainable development; } \cdot \text { No detailed } \\
\text { metrics of social and environmental value are } \\
\text { provided beyond broad sustainable development } \\
\text { goals - which were not able to determine to what } \\
\text { extent the firm is or is not sustainable; } \cdot \text { Although } \\
\text { an in depth literature review is undertaken, the } \\
\text { review is mainly descriptive with little critical } \\
\text { analysis of existing frameworks, and covers many } \\
\text { topics not so relatively unfocused - this said most } \\
\text { existing framework studies do not critically examine } \\
\text { existing frameworks before setting out their own. }\end{array}$ & $\begin{array}{l}\text { - The framework } \\
\text { was not able to } \\
\text { provide a good } \\
\text { understanding of } \\
\text { sustainability. }\end{array}$ \\
\hline 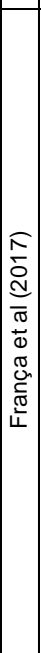 & $\begin{array}{l}- \text { The paper explores } \\
\text { how the framework for } \\
\text { strategic sustainable } \\
\text { development can inform } \\
\text { business model } \\
\text { innovation and design by } \\
\text { combining it with the } \\
\text { business model canvas } \\
\text { and supplementary tools, } \\
\text { methods and concepts. } \\
\text { The tool is applied in } \\
\text { case study. . }\end{array}$ & $\begin{array}{l}\text { - They define and conceptualise a sustainable } \\
\text { society and this is used for the framework. The } \\
\text { framework incorporates a life cycle perspective and } \\
\text { a range of tools such as creativity techniques and } \\
\text { product service systems and value network } \\
\text { mapping. - Good at helping explore potential } \\
\text { transformations to new business models with } \\
\text { potentially greater levels of sustainability; } \cdot \text { A good } \\
\text { tool to apply when exploring transitions and } \\
\text { transformation options for firms that want to innovate } \\
\text { to explore options for helping address sustainability } \\
\text { and can nicely link with the framework for strategic } \\
\text { sustainable development (FSSD) which is also } \\
\text { focused on future visions and transitions. • Applying } \\
\text { the approach, the case study company was said to } \\
\text { be able to transform its vision and strategy from } \\
\text { classic product sales business to a product service } \\
\text { offering with a more sustainable offering; } \cdot \text { Very } \\
\text { useful for exploring potential avenues and scenarios } \\
\text { to and visions for future business models for } \\
\text { sustainability. }\end{array}$ & $\begin{array}{l}\text { - The definition/conceptualisation of a sustainable } \\
\text { society (and principles) do not mention inequality } \\
\text { and allocation or value for whom; · The approach } \\
\text { is said to require researchers, advisors/consultancy } \\
\text { as well as a range of different tools, limiting ability } \\
\text { of firms to readily understand and apply without } \\
\text { substantial cost. • The overall approach is said to } \\
\text { be seldom self-sufficient and by itself does not } \\
\text { provide all information needed for assessing } \\
\text { sustainable development; • Detailed social and } \\
\text { environmental metrics are not provided or in the } \\
\text { FSSD; • Not provided as one integrated tool; } \cdot \\
\text { From application, the reader does not get a good } \\
\text { sense of how exactly the business models } \\
\text { functions, how different elements interact to create } \\
\text { and capture value (in different forms) and for whom, } \\
\text { or the business models sustainability, only relatively } \\
\text { brief overview (similar to most other studies case } \\
\text { studies, in this respect). • Value and its different } \\
\text { forms are not defined; • From results it is not clear } \\
\text { that the approach was able to identify the } \\
\text { sustainability of the case study }\end{array}$ & $\begin{array}{l}\text { - Not a straight } \\
\text { forward model } \\
\text { for practitioners } \\
\text { to apply and } \\
\text { requires } \\
\text { substantial input. } \\
\text { - It was not clear } \\
\text { that application } \\
\text { enabeled in } \\
\text { depth } \\
\text { understanding } \\
\text { on sustainability } \\
\text { and business } \\
\text { model } \\
\text { functioning; }\end{array}$ \\
\hline
\end{tabular}




\begin{tabular}{|c|c|c|c|c|}
\hline & Aim and Contribution & $\begin{array}{c}\text { Main 'Strengths' of framework in addressing } \\
\text { 'sustainable development' and conceptualising } \\
\text { and identifying 'value'. }\end{array}$ & $\begin{array}{l}\text { Main 'Weaknesses' of framework in } \\
\text { addressing 'sustainable development' and } \\
\text { conceptualising and identifying 'value'. }\end{array}$ & $\begin{array}{c}\text { Applicability } \\
\text { for detailed } \\
\text { case study } \\
\text { business } \\
\text { model analysis }\end{array}$ \\
\hline & $\begin{array}{l}\text { - The paper advances } \\
\text { knowledge and } \\
\text { proposes a theory and } \\
\text { practice-based } \\
\text { framework to help } \\
\text { organisations move } \\
\text { towards more } \\
\text { sustainable business } \\
\text { models, making explicit } \\
\text { main elements to align } \\
\text { business to } \\
\text { sustainability. }\end{array}$ & $\begin{array}{l}\text { - Sustainability principles are defined but it is not } \\
\text { clear how these are assessed, as reference is } \\
\text { made more specifically to sustainable development } \\
\text { goals which seem to have been primarily used; } \\
\text { Helpful in aiding businesses to realise ways in which } \\
\text { they may be impacting SDGs; } \cdot \text { Said to be an } \\
\text { attempt to provide deeper understanding of what } \\
\text { makes a business more sustainable in practice; } \\
\text { Novelty of framework is said to be that it is both } \\
\text { theory and practice based and it is said that it } \\
\text { provides relatively concrete indications of how to } \\
\text { implement more sustainable business models; } \\
\text { Considers context generally like Upward and Jones } \\
2016 \cdot \text { Concept of cascadable sustainable value, } \\
\text { said to represent that a business model is part of a } \\
\text { value network, value delivered by the organisation is } \\
\text { captured not only by stakeholders with direct } \\
\text { contact, but this is also deployed to focal company's } \\
\text { stakeholders - however, modelling value through } \\
\text { supply chains is not new, LCA/input-output does } \\
\text { this. }\end{array}$ & $\begin{array}{l}\text { - When exploring sustainability the approach to } \\
\text { assessing sustainability seems to be mainly in } \\
\text { terms of asking firms to identify with SDG's as } \\
\text { show in results of Table } 7 \text {, this does not bring about } \\
\text { in depth evidence or understanding of sustainable } \\
\text { development of the organisations from evidence } \\
\text { presented; - From application of the framework to } \\
\text { results, it is difficult to get a clear understandingand } \\
\text { assessment of sustainability of each organisation, a } \\
\text { later paper using SDGs acknowledges this issue, } \\
\text { seen in Morioka et al (2018); • Detailed social and } \\
\text { environmental metrics to explore sustainability are } \\
\text { not provided in the paper. • Also from reading } \\
\text { results from applying the framework one does not } \\
\text { get an understanding of the specific in depth } \\
\text { functioning of the business model and exactly how } \\
\text { different elements interact to create and capture } \\
\text { value; - Value and its different forms are not } \\
\text { defined. }\end{array}$ & $\begin{array}{l}\text { - No evidence } \\
\text { presented to } \\
\text { show that the } \\
\text { framework was } \\
\text { able to provide } \\
\text { in depth } \\
\text { understanding } \\
\text { on the business } \\
\text { model, how it } \\
\text { creates and } \\
\text { captures value } \\
\text { and its } \\
\text { sustainability. } \\
\text { Does not lead to } \\
\text { in depth case } \\
\text { study } \\
\text { understanding of } \\
\text { exisisting } \\
\text { business } \\
\text { models }\end{array}$ \\
\hline & $\begin{array}{l}\text { - This study develops a } \\
\text { unified theoretical } \\
\text { perspective for } \\
\text { understanding business } \\
\text { model innovations that } \\
\text { lead to better } \\
\text { organisational economic, } \\
\text { environmental and social } \\
\text { performance. }\end{array}$ & $\begin{array}{l}\cdot \text { The paper puts forward five propositions that } \\
\text { support the creation of sustainable business models } \\
\text { (SBMs) in a unified theoretical perspective for } \\
\text { understanding business model innovations that lead } \\
\text { to better organisational economic, environmental } \\
\text { and social performance which is a substantive } \\
\text { contribution to the field; } \cdot \text { The propositions are put } \\
\text { forward after examining literature from relevant } \\
\text { fields; • The propositions lay a foundation that can } \\
\text { support organisations investigating and } \\
\text { experimenting with alternative business models. } \\
\text { The propositions are helpful for guiding investigation } \\
\text { of business models for sustainability in a unified } \\
\text { way; • As with some other studies they recognise } \\
\text { environmental, social and environmental value as } \\
\text { important; • The article provides some interesting } \\
\text { discussion on value from different fields; }\end{array}$ & $\begin{array}{l}\text { - They usefully identify from literature that the } \\
\text { scope of value should include not only economic } \\
\text { transactions but also relationships, exchanges and } \\
\text { interactions taking place among stakeholders, } \\
\text { including the natural environment and society as } \\
\text { primary stakeholders - however a detailed business } \\
\text { model framework focused on the relevant types of } \\
\text { value would be needed to explore this that looks at } \\
\text { value in a defined, nuanced and in depth way (their } \\
\text { study does not attempt this, but advocates future } \\
\text { work to explore relevant variables); } \cdot \text { The goals of } \\
\text { businesses seeking to be sustainable are not } \\
\text { identified - so does not provide guidance on this or } \\
\text { treat with this issue. - Social and environmental } \\
\text { metrics for exploring sustainability are not provided; } \\
\text { - Definitions of sustainable development are not } \\
\text { provided; - Definitions of value/different value } \\
\text { forms are not provided; }\end{array}$ & $\begin{array}{l}\text { - Does not } \\
\text { provide an } \\
\text { framework that } \\
\text { can be applied } \\
\text { for case study } \\
\text { analysis of an } \\
\text { organisations } \\
\text { business model. }\end{array}$ \\
\hline 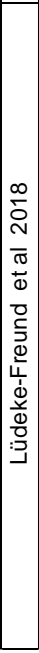 & $\begin{array}{l}\text { - The study develops, } \\
\text { tests and applies a new } \\
\text { multi-mentod and multi- } \\
\text { step apprach focused on } \\
\text { using an expert review } \\
\text { process that combines } \\
\text { literature review as well } \\
\text { as Delphi suvey, and } \\
\text { physical card sorting to } \\
\text { identify and validate } \\
\text { current sustainable } \\
\text { business model } \\
\text { patterns. Effectively they } \\
\text { develop a taxonomy. }\end{array}$ & $\begin{array}{l}\text { A main strengths in their work is addressing } \\
\text { sustainable development are: } \bullet \text { providing rigourous } \\
\text { synthesis and consolidating the liteature on } \\
\text { sustainable business models; } \bullet \text { They develop a } \\
\text { pattern concept as an effective tool to organise } \\
\text { knowledge about different types of sustainable } \\
\text { business models; } \bullet \text { The taxonomy is very usefull to } \\
\text { practitioners in identifying different types of } \\
\text { business models for sustainability and some key } \\
\text { broad characteristics, it can help with sorting, } \\
\text { ordering and retrieving a large ammount of } \\
\text { information about sustainable business models and } \\
\text { characterises whether mainly focused on social, } \\
\text { economic or environmental aspects of sustainability. } \\
\text { - It is said to provide a framework to structure } \\
\text { existing knolwegde on sustainable business models } \\
\text { in terms of sustainability isues, groups or families of } \\
\text { sustainable business models and single sustainable } \\
\text { business model patterns. } \cdot \text { define the notion of } \\
\text { SBM pattern; } \cdot \text { They identify with the idea of social, } \\
\text { environment and economic value throughut the } \\
\text { paper and bring this into their taxonomy approach; }\end{array}$ & $\begin{array}{l}\text { - Primarily provides a framework approach and } \\
\text { system for organising existing knowledge of } \\
\text { existing business models and does not provide a } \\
\text { framework for in depth understanding and case } \\
\text { study analysis of new ones (as this was not the } \\
\text { focus). } \cdot \text { Value are looked at in terms of economic, } \\
\text { ecological, and social value, but no further depth or } \\
\text { discussion; } \cdot \text { Value is not defined; } \cdot \text { Does not look } \\
\text { at or address the issue of value shares from } \\
\text { different business models and value for whom; } \\
\text { This said, these aspects were not really the focus } \\
\text { of the work and like many of the other studies } \\
\text { reviewed above, the work has many merits and } \\
\text { contributions to knowledge and has substantially } \\
\text { furthered the field. }\end{array}$ & $\begin{array}{l}- \text { Not applicable } \\
\text { for detailed case } \\
\text { study analysis }\end{array}$ \\
\hline
\end{tabular}

All of the detailed frameworks applicable to the current study make use of or build on the

Osterwalder and Pigneur's (2010) business model canvas. Of the studies initially reviewed, the 
two most relevant to the current study in terms of provision of a framework for analysis of a firms business model, were Joyce and Paquin (2016) and Upward and Jones (2016). Joyce and Paquin (2016) is relevant because it is a detailed framework suitable for understanding a business model in depth (as the various detailed components of the business model are looked at) and addresses social and environmental aspects. Upward and Jones (2016) is relevant because it is also a detailed framework suitable for understanding a business model in depth (as the various detailed components of the business model are looked at) whilst covering some social and environmental aspects. Importantly it is also the only detailed potentially suitable business model framework that defines the term 'value'. In terms of areas to build on, all papers lacked an explicit definition of sustainable development with clear aims that they apply systematically in assessing sustainability (apart from França et 2017 who define a sustainable society); this is important in developing frameworks that are strategic, focused and effective in looking at sustainable development. A consequence of this is for example that none of the studies explicitly look at equity dimensions of sustainability (França et al 2017 also do not), the first aim of sustainable development. Also, apart from Joyce and Paquin (2016) none of the studies provide detailed indicators for the relevant range of social and environmental indicators - see table 1. Joyce and Paquin (2016)'s approach would benefit from a more strategic and systematic approach in line with the aims of sustainable development and the drivers of key global environmental pressures. Similarly, the study (and other studies) generally do not link in systematic tools used by industry such as ISO 26000 to help identify the range of social impacts that may exist. Equity in resource distribution is not discussed in either of the two frameworks despite it being the first key aim of sustainable development. While the paper was in review, a further four relevant studies were found (Morioka et al 2017; Yang et al 2017; França et al 2017 and Morioka et al 2018). The latter four studies all had a range of different 9 
capabilities and strengths but broadly suffered from the same gaps identified for the other studies reviewed and when viewing results of case studies did not enable an in depth analysis and understanding of the functioning of the existing business model and how all the elements interact together to create and capture different forms of value. They also struggled to determine current sustainability of the organisations they were examining in their results sections (when and if this was attempted) as Seen in Table 1. Morioka et al 2017, trialled the use of the UN Sustainable development goals to help explore sustainability, but this was not demonstrated to lead to a good in depth understanding of the organisations sustainability in results sections.

Business model frameworks generally assume that the main goal of firms is to maximise profit and use the term 'value' as profit related (Teece, 2010; Osterwalder and Pigneur, 2010; Baden Fuller \& Morgan 2010; Zott \& Amit 2010, Upward and Jones 2016). Upward and Jones (2016) is the only framework that defines the term value, however the paper then reconceptualised value into what it terms as tri-profit - three types of (social, environmental and economic) revenues minus costs, where the value component are seen as revenues. For the current paper value is conceptualised as broader than revenue. Bocken et al (2013), identify three opportunities for value innovation for a firm and its stakeholders: opportunities for new value creation; value missed, and value destroyed. However they do not define these as such and merely provide some examples for each. Bocken et al (2013) (and Geissdoerfer et al. 2016a, Kurucz et al. 2017 and Upward and Jones 2016) and some other papers identify value as capable of being 'destroyed'. In this paper we contend that destroying value is not possible if the concept of value is perceptual and co-created in use (Vargo and Lusch 2008). Yang et al (2017) identify and define the concept of value uncaptured; this is useful when exploring future 
strategy and visions of a new business model, but does not identify and define the relevant range of value and forms of existing value from an existing business model. Scope of value should include not just economic transactions but additionally relationships, exchanges and interactions that take place among stakeholders and that can be represented by value flows (Evans et al 2017). Evans et al (2017) also do not define value, but provide a substantive contribution by providing some useful guiding principles that can inform the development of future business model frameworks. They identify the following five principles, that the current paper builds on:

"Principle 1: Sustainable value should incorporate economic, social and environmental benefits conceptualized as value forms;

Principle 2: SBMs require a system of sustainable value flows among multiple stakeholders including the natural environment and society as primary stakeholders.

Principle 3: SBMs require a value network with a new purpose, design and governance;

Principle 4: SBMs require a systemic consideration of stakeholder interests and responsibilities for mutual value creation;

Principle 5: Internalizing externalities through PSS enables innovation towards SBMs."

(Evans et al 2017 p.605)

From the review it was clear that robust and defined definitions and fuller understandings of existing value are required (beyond just goodness of Upward and Jones 2016) as well as alternative, stronger conceptualisation of value destroyed (for the reasons stated earlier). Of the frameworks reviewed, Upward and Jones (2016) is the most suitable framework for 11 
application, but beyond limitations of their conceptualisation of value, the framework is somewhat unclear and resource intensive for practitioners (also the case for a number of other frameworks). We contend that organisations and policy makers should incentivise the development, adoption and application of business models that act as epistemic objects (Knorr Cetina, 2001). Such objects are dynamic means of knowledge sharing that show organizational complexity in terms of scope and interdependencies and initiate discussion. Application generates greater understanding and highlight sectors that are more or less sustainable.

In response to the gaps identified above, this paper develops a framework for detailed case study analysis of existing business model in terms of their sustainability. The framework needs to 1 . Outline clear goals aligned with definition and aims of sustainable development; 2 . Define and conceptualise the full range of value relevant to the existing business model; 3 . Assess sustainable development of the business model based on the extent to which it addresses the three key aims of sustainable development and link to systematic approaches such as ISO 26000 to identify the relevant range of indicators.

\section{Research Method}

A two-step approach was used to develop and test the framework; first, a process of cooperative enquiry with practitioners to iteratively develop a business model framework; second, an in depth case study with an energy provider making use of the final version.

\subsection{Co-operative enquiry}

Co-operative enquiry was run with businesses participants in April 2015. Participants were directors, business managers and entrepreneurs. Given that there were a number of firms and that a dialogue about firms' experience from application was required, workshops were the 12 
most suitable method. Workshops are an appropriate method in developing new frameworks, gaining new understanding on categories and questions and how they should be developed. The selection criteria for inclusion of workshop participants was based on whether they had an interest in developing business models to be more sustainable. The procedure for the workshops was as follows:

1. A recruitment email was sent to a list of environmentally aware businesses that the university had collated this included the topic for the day and what they would gain from attending, as well as details about participating and how to respond to take part;

2. The organisations that responded, attended the workshop held at the University and were provided participant information sheets and informed consent forms to sign before participating;

3. Participants were then introduced to standard business model frameworks and these were explained (Baden-Fuller, C., Mangematin V., 2013, Osterwalder and Pigneur 2010) and the initial pilot framework developed in this study;

4. Participants were then asked to use the pilot framework to identify their current business model (The pilot framework is provided in Appendix A along with questions asked of participants in the session) - researchers were also on hand answer questions;

5. Participants were then asked to present their work to the group and be prepared to answer questions;

6. Data from the workshop was collected though participants filling out the business model canvas presented to them. Once canvases were complete, answers to each category of the initial pilot were assessed for clarity and completeness, this helped explore if categories needed further guidance/development. 


\subsection{Case study}

Building on the workshop a business model framework was then finalised and applied in a single in-depth case study (Yin, 2009) with an energy services company. The case study applied an interview approach, working with two members of the directorate, as this provides depth of focus, information and understanding of a business and creates an environment where leaders can freely discuss the business model. The core selection criteria for the case study was concern for including social and/or environmental issues into the business model of the $\operatorname{organisation}^{1}$.

In the case study, the two directors are given the pseudo names James and Deborah. Interviews were semi-structured, but adaptive to capture important emergent information; this reflects the qualitative nature of the process (Kleining 1998). Specific business model interviews were undertaken in one day for two hours. Specific questions asked in the interview (as part of the framework) are provided in Appendix C. The case study company is private, but a major shareholder is the Local Authority which is also their primary customer. The energy company (ECompany) is a unique case, being a business reporting to a public sector organisation. The energy company specialises in low carbon energy provision, electricity, heating and cooling

\footnotetext{
${ }^{1}$ Essentially the case study was selected as it was an organisation that had attempted to incorporate these aspects into it's business model. Applying our framework with such an organisation allowed us to explore the the framework's capabilities in in depth case study analysis to fathoming exactly how the business model works, how the different components interact to creates and captures different types of value and for whom, and its sustainability.
} 
services. Single case studies are appropriate when testing theory or frameworks, or conducting a unique case study (Yin 2009). The current research is fits Yin's rationale of testing theory or a framework and is also a unique case study. The business model case study company, has never before had its business model documented.

For interviews, data was collected for each question of each category/component of the framework in interviews. The data was then transcribed. Each component/category was then assessed by reviewing answers to each of the questions asked for the relevant component, to ensure that all salient details were identified to address each components/categories of the framework. On a small number of occasions information was given relating to one question of the framework that also helped in answering another component of the framework, if this occurred, then data was transferred across to the relevant component that was being addressed. Where further detail was required to explore each category/component, then the researcher asked for further information relating to the relevant question of the framework from the particpants to complete the analysis. 


\section{The framework and case study application}

Five gaps and ways of extending Osterwalder and Pigneur (2010) emerged from the literature review of frameworks. The five main ways that the framework needed to be extended were as follows: 1.) To provide a definition of sustainable development with clear aims that the framework can use to assess sustainability and that are tractable throughout the analysis - the literature review identified gaps here particularly in addressing the inequality/value for whom; 2.) to provide clear goals for the business model for sustainable development (differing from the standard profit maximisation)- the literature review identified gaps here. Evans et al (2017) recently identify society and environment as primary stakeholders for sustainable business models; goals of business models need to reflect this; 3.) To define and conceptualising existing value (the full range of value) relevant to addressing sustainable development and build into the framework - the literature found gaps/issues in definition and conceptualisation of value; 4. To incorporate the individual/organisation/society categorisation of value (Lepak et al., 2007) as this helps assess sustainable development and value creation and capture for whom and helps understanding of relationships, exchanges, and interactions that lead to creation and capture of value (and business model functioning), literature review identified as important; and 5.) To incorporate the ISO 26000 Social Responsibility indicators into the framework to enable systematic scoping of sustainable development via observing social and environmental indicators - the literature found gaps in existing framework building in systemic industry relevant metrics to explore sustainability.

\subsection{Definition of key concepts}




\subsubsection{Sustainable development}

The Brundtland definition of sustainable development (WCED 1987) is applied in the framework as it is a widely accepted starting point for scholars and practitioners focused on environment and development dilemmas and encompasses environmental, social and economic dimensions that were made explicit in Elkington $(1997)^{2}$. This definition is used in combination with the three key aims set out at the beginning of this paper which aid clarity, focus and robustness of the framework in assessing sustainability. Sustainable development is assessed in this study by assessing the case study business model in addressing each of the three aims. Due to the being widely used, the definitions and assessments are more likely be consistent with definitions of larger entities such as regions and national governments and nongovernmental organisations tackling sustainability, this increases chances of consistency across entities. This is a useful characteristic as sustainable development is a systems problems and requires systems solutions across entities, so a definition that can span beyond individual businesses has greater chances of alignment as part of a systems approach.

\subsubsection{Value and goals for the framework}

The framework of this paper defines and conceptualises value in three ways relevant to sustainable development: use value; non-use value; and exchange value.

Use value refers to "the specific quality of a new job, task, product or service as perceived by users in relation to their needs (and context)" (Lepak and Smith 2007 p.182). Following Plottu

\footnotetext{
${ }^{2}$ It should however be made clear that the Triple Bottom Line was not used in the current study as it was found to not be appropriate for the current study, as identified in the main text.

17
} 
and Plottu (2007), this can be extended to value reflecting the satisfaction that the individual derives from using the resource. Use value also includes option value (Weisbroad 1964), that is the value of conservation of an element in view of its possible future use.

There are two main types of non-use value: existence and bequest value (Krutilla, 1967). Existence value is that which individuals perceive due to the existence of items or environmental assets that individuals enjoy. Bequest value is the belief that future generations will inherit an item or environmental asset of value to them.

Exchange value is defined as: "either the monetary amount realised at a certain point in time, when the exchange of the new task, good, service, or product takes place, or the amount paid by the user to the seller for the use value of the focal task, job, product, or service" (Lepak and Smith 2007 p.182). Where markets do not exist, exchange value is sometimes translated (via estimations) from use/non-use value though a range of approaches with varying success (Perman et al. 2011).

Value can be created and captured for and by individuals, organisations and society (Lepak and Smith 2007). Individual, organisational and societal value may be perceived by different actors at different times (Lepak et al., 2007). The current paper therefore synthesises the three level perspective into the framework to explicitly enable the assessment of distributional aspects of the business model, i.e. what value is being created and for whom? Evans et al (2017) identify an additional stakeholder as the natural environment.

In the framework the goal of profit maximisation (revenues minus costs for an organisation) is substituted with value maximisation. Recent empirical evidence shows that many managers, whilst focussed on financial sustainability of the organisation, also seek to increase value for 
society and their own wellbeing, satisfying a diversity of psychological motivations (Webber et al. 2017, Seyfang et al. 2013). Evans et al (2017) identify society and the environment as primary stakeholders for sustainable business models. This said we identify that a sustainable business model must be economically viable in the first instance so creating sufficient value for the business owner and workers to sustain themselves comfortably. On this basis the framework sets out the following goals for business models for sustainable development:

First, financial worth is captured sufficiently for the firm to remain viable and sufficiently invest. Second, once a business model for sustainable development is financially viable, organisations (aligning themselves with sustainable development) prioritise maximisation of value for society (as opposed to organisations or individuals) whilst minimising dis-value for the natural environment and society.

Business models looking to maximise value should recognise that a firm's business model may create 'dis-value', which the current paper defines as damage to humans' 'capabilities to flourish' (Sen 1999). If focusing on the environment as a stakeholder then dis-value is defined as: damage inflicted on the environment and earths systems contributing to transgressing ecological limits and jeopardising integrity of ecological systems. Quite a number of the key ecological limits are set out by Steffen et al (2015). Dis-value essentially detracts from value that a business model can create. If attempting to maximise value, a business model should aim to avoid dis-value.

The focus and clarity on value (and dis-value) and the related goal (value maximisation) allows the framework and it's goals to be conceptually robust, clear, coherent and aligned with addressing sustainable development. 


\subsection{Defining components and applying the framework}

From application in the workshop it was found that Osterwalder and Pigneur (2010) helps take managers through a wide range of aspects of the business model and helps one to understand and articulate the business model. Additionally, from the review of the sustainable business frameworks it was also found to be the most widely used framework of the ones applicable for more detailed analysis. Morioka el al (2017) identify it as the most disseminated in practice more generally, therefore businesses as well as academics will be familiar with it, which makes application of the framework more straight forward for practitioners. On this basis this framework is extended to deliver the framework required for the current study. Table 2 identifies components of the framework including new categories and extensions that were made to enable the framework to deliver in depth case study analysis of business models for sustainable development. The new categories displayed in Table 2 were created in response to gaps identified in the literature review and from experience gained in workshops that showed that value needed to be looked at by the framework in a more nuanced, in depth way e.g. different forms of existing value and for whom and a consideration of how context shapes value. The framework needed to be designed to help unpick the different relationships, exchanges and system interactions that lead to value creation and capture by the business model (as Evans et al 2017 identify as important from their review). The three new categories value for individuals, the organisation and society and the environment, and use of value proposition in context when used in tandem with the other components enable this in depth understanding. The categories were primarily created based on realising the benefit of incorporating the three level perspective of Leepak et al (2007) explicitly into framework, as well as from synthesis of literature about value that showed the importance of context in understanding value creation and capture.

20 
Table 2: New categories and extensions to the Osterwalder and Pigneur (2010)

\begin{tabular}{|c|c|c|}
\hline Component & Definition & Extended Framework \\
\hline $\begin{array}{l}\text { Value } \\
\text { proposition }\end{array}$ & $\begin{array}{l}\text { Describes bundles of products and services used to create } \\
\text { value for customer segments (Osterwalder \& Pigneur, 2010). }\end{array}$ & $\begin{array}{l}\text { Builds on previous frameworks: Osterwalder \& Pigneur, } \\
2010 \text {; and building in whether scale or bespoke offer from } \\
\text { Baden-Fuller \& Haefliger } 2013 \text { as this helps understand the } \\
\text { business model. }\end{array}$ \\
\hline $\begin{array}{l}\text { Customer } \\
\text { segments }\end{array}$ & $\begin{array}{l}\text { The different groups of people or organisations an enterprise } \\
\text { aims to reach and service (Osterwalder \& Pigneur, 2010) }\end{array}$ & Uses Osterwalder \& Pigneur 2010 \\
\hline $\begin{array}{l}\text { Customer } \\
\text { relationships } \\
\text { and sensing }\end{array}$ & $\begin{array}{l}\text { Types of relationships a company develops with customer } \\
\text { segments (Osterwalder \& Pigneur, 2010). } \\
\text { Sensing establishes what customer-users need (Baden- } \\
\text { Fuller \& Haefliger 2013) }\end{array}$ & $\begin{array}{l}\text { Extends Osterwalder \& Pigneur } 2010 \text { customer relationships, } \\
\text { to include Baden-Fuller \& Haefliger } 2013 \text { customer sensing, } \\
\text { capturing the relationships between beneficiaries. }\end{array}$ \\
\hline $\begin{array}{l}\text { Key } \\
\text { stakeholders } \\
\text { and Partners }\end{array}$ & $\begin{array}{l}\text { Key partners are the network of suppliers and partners that } \\
\text { make the business model work (Osterwalder \& Pigneur, } \\
\text { 2010). }\end{array}$ & $\begin{array}{l}\text { Extends Osterwalder \& Pigneur } 2010 \text { to include stakeholders } \\
\text { beyond investors and suppliers. Captures who has influence } \\
\text { or is impacted. }\end{array}$ \\
\hline Key activities & $\begin{array}{l}\text { The most important things a company does to make its } \\
\text { business work (Osterwalder \& Pigneur 2010). }\end{array}$ & $\begin{array}{l}\text { Descriptors of what the firm does, used in Osterwalder \& } \\
\text { Pigneur } 2010 .\end{array}$ \\
\hline Key resources & $\begin{array}{l}\text { The most important assets required to make the business } \\
\text { model work (Osterwalder \& Pigneur 2010). }\end{array}$ & $\begin{array}{l}\text { Extends Osterwalder \& Pigneur } 2010 \text { to examine material } \\
\text { flows as this is key to addressing the first aim of sustainable } \\
\text { development }\end{array}$ \\
\hline $\begin{array}{l}\text { Channels, value } \\
\text { chain and } \\
\text { linkages }\end{array}$ & $\begin{array}{l}\text { Companies use channels to communicate with and reach } \\
\text { customer segments to deliver a value proposition } \\
\text { (Osterwalder \& Pigneur 2010).Value Chain and Linkages are } \\
\text { mechanisms used by firms to deliver products/services to } \\
\text { customer segments (Baden-Fuller \& Mangematin, 2013) }\end{array}$ & $\begin{array}{l}\text { Extends Osterwalder \& Pigneur } 2010 \text { to include Baden-Fuller } \\
\text { \& Mangematin } 2013 \text { value chain and linkages. Value often } \\
\text { falls on different actors along a supply chain as do } \\
\text { environmental and social benefits/damages (Bradley et al } \\
\text { 2013), vertical integration can often be important in creating } \\
\text { and capturing value. }\end{array}$ \\
\hline Cost structure & $\begin{array}{l}\text { All costs incurred to operate a business model (Osterwalder } \\
\text { and Pigneur 2010) }\end{array}$ & $\begin{array}{l}\text { Builds upon Osterwalder and Pigneur 2010, to consider } \\
\text { dynamics such as minimising cost, economies of scale but } \\
\text { also distribution of costs. }\end{array}$ \\
\hline $\begin{array}{l}\text { Value for } \\
\text { individuals }\end{array}$ & $\begin{array}{l}\text { Individuals seek financial reward for their contribution to the } \\
\text { organisation, but are increasingly interested in the core } \\
\text { values of the firm (Porter and Kramer, 2011) }\end{array}$ & $\begin{array}{l}\text { New category critical in assessing sustainable development; } \\
\text { builds in Lepak et al., } 2007 \text { definement of value to 'individual, } \\
\text { organisation and society'. Includes financial and use value } \\
\text { benefits evidenced with salary (or other) data, and can } \\
\text { explore motivations and values. }\end{array}$ \\
\hline $\begin{array}{l}\text { Value for } \\
\text { organisations }\end{array}$ & $\begin{array}{l}\text { Assessment of the value generated by the firm via observing } \\
\text { profit of the firm, including assessment of investment and any } \\
\text { non-monetary value captured (the latter non-monetary aspect } \\
\text { is from Parry \& Tasker 2014, 'Worth Capture'). }\end{array}$ & $\begin{array}{l}\text { New category critical in assessing sustainable development; } \\
\text { builds in Lepak et al. } 2007 \text { definement of value to 'individual, } \\
\text { organisation and society'. Explicitly looks at financial } \\
\text { sustainability of the organisation and other value generated by } \\
\text { the organisation. Advances the basic revenue/monetisation } \\
\text { categories of Osterwalder \& Pigneur } 2010 \text { and Baden-Fuller } \\
\& \text { Mangematin } 2013 \text { that are only price and revenue focused } \\
\text { (this is not a measure of the economic viability or } \\
\text { sustainability of the firm). Consider financial but also non- } \\
\text { financial value if relevant. }\end{array}$ \\
\hline $\begin{array}{l}\text { Value for } \\
\text { society and the } \\
\text { environment }\end{array}$ & $\begin{array}{l}\text { Value is co-created in use by the customer who is situated in } \\
\text { specific contexts (Vargo and Lusch, 2008). Definition } \\
\text { extended to recognise other stakeholders use of a value } \\
\text { proposition in context will also shape value and dis-value for } \\
\text { wider stakeholders. }\end{array}$ & $\begin{array}{l}\text { New category critical in assessing sustainable development; } \\
\text { builds in Lepak et al., } 2007 \text { definement of value to 'individual, } \\
\text { organisation and society' This category examines } \\
\text { value/impacts created beyond the firm at the societal level. } \\
\text { Indicators brought together to attempt to identify an } \\
\text { organisations wider social, environmental and economic } \\
\text { impact. We also recognise the environment as a stakeholder } \\
\text { and the importance of not creating dis-value for the } \\
\text { environment as well as society. }\end{array}$ \\
\hline $\begin{array}{l}\text { Use of a value } \\
\text { proposition in } \\
\text { context }\end{array}$ & $\begin{array}{l}\text { Organisations are open systems interacting with and } \\
\text { impacting upon their environment (Daft, 2007), and this } \\
\text { broader impact both positive and negative represents value } \\
\text { for society and the environment. }\end{array}$ & $\begin{array}{l}\text { New category that looks at the use of value propositions by } \\
\text { customers and other stakeholders and how this shapes } \\
\text { value creation, capture and dis-value generated by an } \\
\text { enacted value proposition. Provides a broader } \\
\text { conceptualisation of value as perceived and (dis-value and } \\
\text { value) as being dynamic and shaped by context. }\end{array}$ \\
\hline
\end{tabular}


An analogy of the business model as a torch light, was developed with organisations for helping explain the different aspects of the business model and function together. The 'torch light framework' is presented in Figure 1.

\section{Figure 1: 'The torch light framework'.}

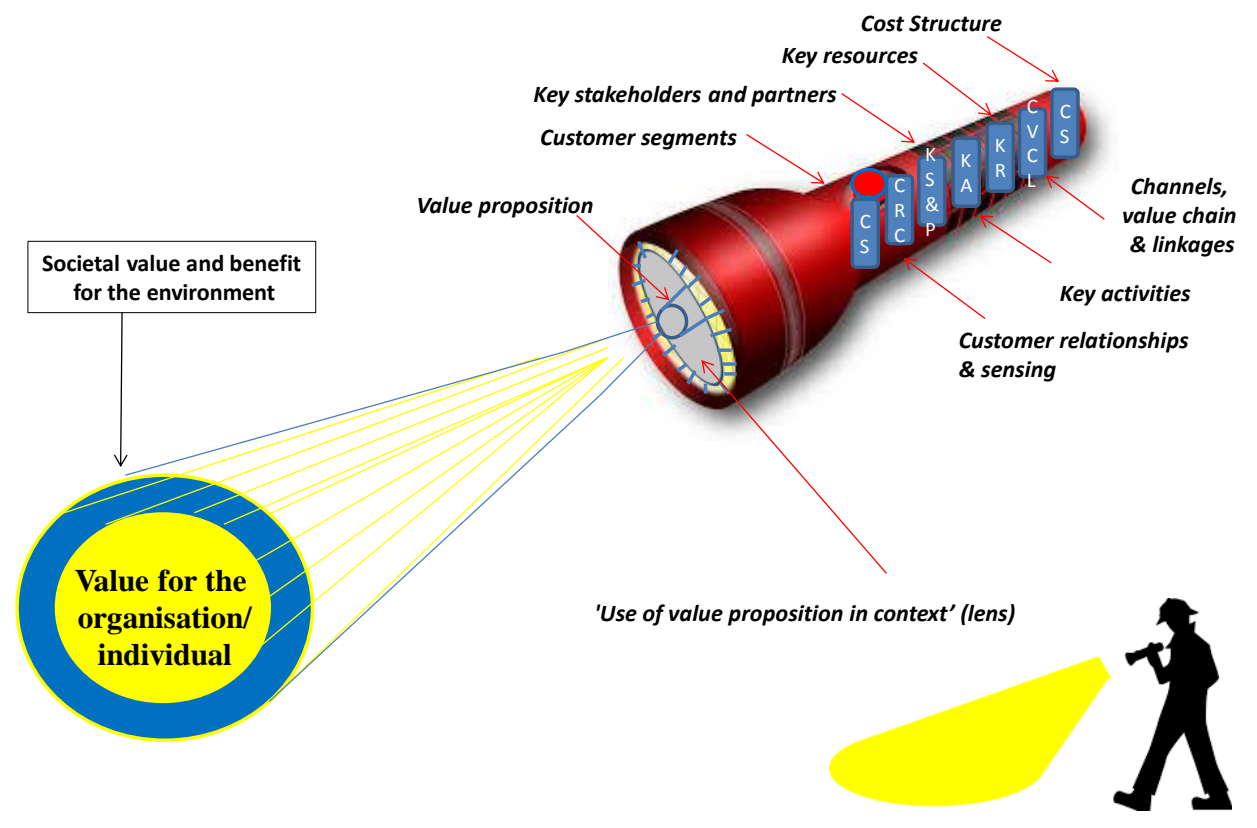

The torch light framework works conceptually to describe the business model components and their interaction with each other that lead to the emergence of value (light) for different stakeholders: individuals, organisations and society and the environment. The analogy demonstrates that part of value captured by individuals and organisation (the yellow) and that which goes to wider society and the environment (blue). Essentially these shades of light (yellow and blue) will be larger or smaller depending on the nature of the business model and its functioning. Dis-value can reduce the 'goodness' that a business model achieves (impacting the light for society and the environment). A business model is part of a complex system, and in such systems value to individuals, organisations and society and the environment emerges 22 
as a results of the interaction of the different components of the business model in tandem with the wider system and context. The different torch light (components) that interact to enable light to come forth are used as an analogy to represent this interaction of the different component with the wider system (context) that lead to the emergence and co-creation of value in different forms for different stakeholders.

\subsubsection{Value proposition}

The value proposition is the firm's offering and this element describes the issue or challenge that a company solves for the customer and the products and services required to deliver the proposition. The value proposition captures the form of engagement, and describe whether it is delivered at scale or bespoke (this also connects with value created). To capture information on value, proposition specific questions were developed with practitioners to help better capture the nature of the value proposition. Specifically, participants were asked for a description of what the firm offers to its customers; 'what is the issue or challenge the organisation solves for the customer?' and 'Is the offer solving a challenge at scale or bespoke?'

\section{Case study value proposition example}

ECompany addresses three challenges for the Council simultaneously: first, implementation of policy relating to delivering on environmental, health and wellbeing; second is helping job creation in the Council area they represent; third is economic development. The value proposition of ECompany was summarised as follows: "affordable, low carbon energy delivery to meet local and national government energy policy at minimum cost, which attracts certain businesses to site themselves in local areas served and through these activities, enhance the reputation of the Council locally and globally" (Mr James). 
Critically, economies of scope lie at the heart of the functioning of this business model and its value. By keeping energy generation and distribution locally in house, there is efficiency and control in meeting the energy and environmental objective, but at the same time it localises value from energy and additionally attracts certain businesses to site themselves in the local area (bringing further local value) fulfilling the economic objective. The current framework finds that the main benefits of this alternative energy business model lie within its economies of scope. The offerings are predominantly scale related for energy services and bespoke for Council services.

\subsubsection{Customer segments}

Here the aim is to seek to understand the groups of consumers who utilise the value proposition. Managers are asked to consider if an offering focuses on a mass market or particular segments. Are there specific segments they recognise and target and if so what defines them? Do they target many segments or very few? Do they serve a single customer group with the same need or do their customers have different needs? Customer segments only appear in Osterwalder and Pigneur's 2010 business model canvas.

\section{Case study customer segments example}

Based on interview data, three main customer segments were predominantly identified; business (public sector/commercial) and domestic energy customers and the Council (the latter predominantly pay exchange value to the company for cost effective policy implementation). ECompany places specific strategic focus on segments of the energy supply market; domestic and commercial energy customers that are geographically located in Council areas and sometimes in social housing. 
The Council, domestic and commercial energy customers are very different in terms of needs and the services provided to them. Domestic energy customers' needs are primarily to have affordable and secure energy. Commercial energy customers' needs are the same, but some specifically want to gain the benefit from the low carbon energy system. The Council wants to see implementation of environmental/energy policy and promotion of related activities that enable policy, not increasing council tax (exchange value) and the resulting reputational (use and exchange value to individual Council members) and economic and employment benefits the area will gain (use and exchange value). Mr James stated: "the true value of what we do is that if we enable politicians to be re-elected as they are seen to be doing the right thing, they will continue to fund their ownership of ECompany. So there is a democratic value". He also stated: "why does the Council want us to do it? It's enabling the local community to benefit from lower carbon energy".

There is a strong link between the reputational needs of the Council; the satisfaction, provisioning of affordable local energy; and implementation of low carbon energy policy not impacting council tax; essentially, economies of scope exist here. Consultancy to commercial organisations is another segment, but only $1 \%$ of revenue.

\subsubsection{Customer Relationships and Sensing}

Customer relationships and sensing examines the relationships and the costs involved in those customer relationships and which users are paying. Customer relationships from Osterwalder and Pigneur (2010) is extended to also capture customer sensing from Baden Fuller and Mangematin (2013) as this is key to sustainability focused business models where there may be numerous users/beneficiaries. Customer relationships is extended by describing relationships and asking: 'are users paying?', 'If not, who are the other users?'. 


\section{Case study customer relationships and sensing example}

ECompany have three different sets of paying customers. The value that customers gain is linked: 1. local energy customers (energy consumption and DSR); 2. the Council (low carbon/decentralised energy policy implementation); 3. industry and other customers (low carbon technology consultancy). The relationships are described: domestic energy customers one to one, personal; commercial energy customers - one to one, personal; consultancy personal; Council - strongly personal. Having a personalised relationship improves energy customer relations that are perceived to be of benefit to the reputation of the Council who ECompany serve. A closer relationship with customers also helps with debt collection from energy bills. Both energy consumers and Council customers pay ECompany directly.

\subsubsection{Key Stakeholders and Partners}

Key stakeholders and partners captures information about the network of suppliers and partners that make the business model work but importantly also other key stakeholders beyond investors and direct collaborators. The literature on sustainable business models show key stakeholders to be important, so the framework was extended to include this category as well as partners. In investigating this element it is important to ask: 'Who are the key stakeholders and partners?' It should be recognised that outcomes from the business model can have implications for key external stakeholders (beyond the organisation, its supply chain and partners) such as society and the natural environment.

\section{Case study key stakeholders and partners example}

Key stakeholders and partners were described as the Council who represent interests of society and the environment (though local policy and investment) and the UK government through setting combined heat and power policy [CHP]. ECompany can make use of the CHP 26 
opportunities (and renewables) that exist within the built environment, particularly Council owned buildings (a physical context enabling value creating opportunities). Other key stakeholders are the council electorate, energy customers, the commercial gas provider, the grid and wider population.

\subsubsection{Key activities}

Key activities are the descriptors of what the firm does, such as 'problem solving' or 'metal cutting'. This category is from Osterwalder and Pigneur (2010). There is a need to ask the firm: 'What are the key activities of your organisation?' and explore with them throughout the interview.

\section{Case study key activities example}

Key activities of ECompany include: generation of electricity, heating and cooling; distribution, metering, billing systems; maintenance; governance and administration; dissemination of information. A lot of the key activities also relate to developing a good reputation for the Council, such as engaging with industry conferences and hosting visitors; and information dissemination - the website is also an important distribution channel for this. These later activities relate primarily to individual value for Council members via being seen to deliver on policy and govern well.

\subsubsection{Key resources}

Due to the focus on business models for sustainable development, this category is extended to capture material flows into production (as well as physical assets, intellectual property, human resources, skilled workers, financial resources etc). This critical extension is conducted as it is a suitable further way to look at how firms shape resource distribution (the first aim of 
sustainable development). It also helps assess the third aim of sustainable development as it is the flow of key materials through society that is driving key global environmental pressures (Allwood et al 2011). This can be deduced from direct questions and purchasing information. The interviewees are asked 'What are the key resources of the organisation?' These are discussed with the company and the main physical inputs to production /service provision identified.

\section{Case study key resources example}

Key resources of ECompany were said to be as follows: Expertise; financial capital; physical assets, buildings, cable, technology and demonstration technology; management resources; renewables and gas. The resource use in terms of annual gas use by ECompany (their main variable material input) in the council area is $\sim 14,473 \mathrm{MWh}$.

\subsubsection{Channels, value chain and linkages}

This category focuses on the firm's methods of distribution of the product or service and the channels of engagement with stakeholders across a supply chain. Channels are included in Osterwalder and Pigneur (2010) but the framework is extended to include the value chain and linkages category of Baden Fuller and Mangematin (2013). This allows researchers to categorise firms as integrated, hierarchical or networked, particularly important in relation to creating and capture of value in the energy sector as well as other sectors such as water (Bradley et al 2013). Key to this category is to identify the company's main stakeholders in their supply chain (this may come out from questions on key stakeholders) and ask: 'Is the supply chain integrated, hierarchical or networked?' In relation to channels, the key question to ask here is: how do you communicate and reach your customers to deliver a value proposition? 


\section{Case study channels value chain and linkages example}

In terms of value chain and linkages, ECompany are a vertically integrated firm where all the value is co-created with customers and delivered by the organisation with little outsourcing ${ }^{3}$. Mr James stated: "This enables the company to see the system wide benefit directly" and "Being vertically integrated allows the capture of value, otherwise not possible". In terms of channels energy customers are communicated to through owned (and direct) channels such as the website, in house sales/customer services team and billing. An owned maintenance part of the company also provides support in ensuring distribution and delivery to energy customers. A lot of the face to face and online channels are used in developing a good reputation for the Council, by engaging with and disseminating good practice at industry conferences as well as hosting visitors, the website is also an important distribution channel for this. In terms of channels of engagement between the company and its Council customer, this is primarily through face to face and online engagement.

\subsubsection{Cost Structure}

Managers identify the main costs of operating their firm. It is important to identify fixed costs and variable costs (proportionate to activity). This category is adapted from Osterwalder and Pigneur (2010). Other questions relate to how organisations minimise costs and what economies of scale (volume lowers costs) or scope (breadth of offer lowers cost) might exist. Forward thinking organisations will also assess potential costs to their firm from being engaged

\footnotetext{
${ }^{3}$ Mr James explained: "We start with technology, we have two inputs to the technology, one is raw material gas, and one is the operation and maintenance, the operation and maintenance is carried out by ECompany, the raw material is converted into product, we sell the product, we meter it, we bill for it, and we receive revenue for it. We have our own distribution network, metering and own billing system". 
with suppliers that are not contributing to sustainable development and have an adverse effect on the environment or society. The main questions are: 'Please identify the main costs of operating the business?', 'What fixed and variable costs do you have?', 'How do you minimise costs?', and 'What economies of scale or scope exist?'

\section{Case study cost structure example}

The main fixed costs are salaries for company staff (individual value for employees). Other fixed costs relate to energy engineering equipment for $\mathrm{CHP}$ and other forms of decentralised generation, distribution and transmission e.g. having a private wire. The main variable cost is the gas input to producing electricity and energy services. Economies of scope exist by the company conducting energy generation and distribution locally and in house, this increases efficiency (reduces cost) in meeting energy and environmental objectives and localises value from energy of benefit to the community (addressing the Council's economic objective).

\subsubsection{Value}

'Value' includes the value created and captured for different stakeholders. Such a category is not provided by Osterwalder and Pigneur (2010), Baden Fuller and Mangematin (2013) or Parry and Tasker (2014) or the frameworks of Joyce and Paquin (2015) or Upward and Jones (2016), but is critical in understanding business models where value for different stakeholders is a key objective not just profit. Value is examined in use value, non-use value, exchange value and dis-value form and from multiple perspectives: individual; organisation and society and the environment. This allows the analyst to explore the different types of value for different stakeholders and distributional outcomes, i.e. "value or resource allocation for whom?". It also provides understanding on individual motivations to engage with the business model. 
Value to the individual: Individuals seek financial reward for their contribution to the organisation. Beyond individuals in organisations, consumers/users of a value proposition gain value from the goods and services; a proxy of this individual value (although imperfect) is their willingness to pay. Individuals sometimes gain value from fulfilling motivations beyond money. The latter may be explored through values and core purpose.

\section{Case study value to the individual}

ECompany directly employs 5 full time equivalent people and approximately 1.5 full time equivalent staff (individual exchange and use value) in their maintenance services company dedicated to maintenance and operation of assets. The services of ECompany help the Council implement policy cost efficiently, which helps them get re-elected, which is of use and exchange value to individuals in the Council. As a measure of use, value of the services provided to energy customers, this is indicated by the total revenue figures (around $£ 3$ Million in 2014), this provides a measure of willingness to pay for the services (primarily energy services). The above demonstrates the different elements of value created for key individuals.

Value to the organisation: This category helps identify the value created and captured for the organisation. A revenue/monetisation (pricing) category is provided in Osterwalder and Pigneur (2010) and Baden Fuller and Mangematin (2013). These are however not a good measure of financial sustainability of the organisation. The monetary value added and financial sustainability of the organisation should be observable in the profit and loss accounts for the company. Additional questions from Baden Fuller and Mangematin (2013) can be asked if required on revenue streams, such as when, what and how money is raised, and what are their financing options? This adds additional detail if required. 
Capture of value for the organisation does not necessarily have to be in exchange value form (Lepak et al. 2007); it can manifest in many ways such as social capital, such as Facebook likes or addressing aims, mission etc. Researchers can ask what other forms of non-financial value the organisation creates, to pick up on this.

\section{Case study value to the organisation}

Paid for services that ECompany provide and monetary exchange value that they capture, can be split into four categories: domestic and commercial energy provision (organisational exchange value); demand response (organisational exchange value); low carbon technology demonstration/policy consultancy, (organisational exchange value - less than $1 \%$ of turnover); local policy delivery for the Council (organisational exchange value - investment funding by Council).

Analysis of the profit and loss accounts provide a quantitative understanding of the value captured by the firm. The firm makes an operating profit from its energy related products/services and this has been increasing year on year for previous years, with 2015 being over half a million pounds, so the business case for such models is sound. The Council finances the company to ensure policy implementation and the various other activities and benefits that arise from ECompany's action. Money is loaned to ECompany, and the Council receive interest (organisational exchange value) on these loans (around 5\%). Currently the annual interest payments consume all of ECompany's operating profit. Due to steady increases in operating profits their operating losses have been reducing year on year for the previous five years. A further indicator/test of financial sustainability is whether ECompany has sufficient current and fixed assets to cover totals debts. The company has net assets of over $£ 1.5$ million accounting for amounts owed to creditors falling after more than one year. Effectively the operation is 32 
economically sustainable. If the Council were to seek to implement the policies on their own there could be significant cost (and added risk) with implications for the council taxpayers. Additionally, unless they have strong environmental drivers for energy generation an area may revert to national providers (coal could be used). The Council having a major investment in ECompany allows them some influence in the organisation's direction, and societal use value that is generated such as energy independence and the low carbon network.

Value to society and the environment: Value and dis-value encountered by society and the natural environment can be directly produced by an organisation's actions. A proposition may add value, be neutral or dis-value existing social and natural environment/natural capital. Disvalue might be in the form of environmental impacts such as pollution, resource use, ecosystem damage resulting from production and consumption etc., or it could be in the form of social impacts such as negative impacts on health and wellbeing resulting from production or consumption or wider economic benefits from the business model. Measures and approach for assessing societal value are outlined below.

In terms of societal value the ISO 26000 responsibility standards are used as a way to check wider social, economic and environmental value/dis-value beyond the value for the individual and organisation already discussed. This ISO standard was chosen as it is highly regarded around the world and widely used by businesses internationally, so businesses around the world are familiar with and respect it, many companies will already be collecting data aligned with their ISO systems. This is why we incorporate the internationally accepted industry standard into the framework. Given the urgency of environmental pressures a prioritised and detailed approach to address these is also provided in Appendix $\mathrm{C}$ for firms that may not have access to ISO 26000 standards etc. 
Table 3 Indicators from the ISO 26000 social responsibility standards

\begin{tabular}{|c|c|c|c|c|c|}
\hline \multirow[t]{8}{*}{$\begin{array}{l}\text { Human } \\
\text { rights }\end{array}$} & Due Diligence & \multirow[t]{5}{*}{$\begin{array}{l}\text { Fair operating } \\
\text { practices }\end{array}$} & Anti-corruption & \multirow[t]{7}{*}{$\begin{array}{l}\text { Consumer } \\
\text { issues }\end{array}$} & $\begin{array}{l}\text { Fair marketing and contractual } \\
\text { practices, factual and unbiased } \\
\text { information }\end{array}$ \\
\hline & Human rights risk situations & & Responsible political involvement & & $\begin{array}{l}\text { Protecting consumers health and } \\
\text { safety }\end{array}$ \\
\hline & Avoidance of complicity & & Fair competition & & Sustainable consumption \\
\hline & Resolving grievances & & $\begin{array}{l}\text { Promoting social responsibility in } \\
\text { the value chain }\end{array}$ & & $\begin{array}{l}\text { Consumer service, support, } \\
\text { complaint and dispute resolution }\end{array}$ \\
\hline & $\begin{array}{l}\text { Discrimination and vulnerable } \\
\text { groups }\end{array}$ & & Respect for property rights & & $\begin{array}{l}\text { Consumer data protection and } \\
\text { privacy }\end{array}$ \\
\hline & Civil and political rights & \multirow{8}{*}{$\begin{array}{l}\text { Community } \\
\text { involvement } \\
\text { and } \\
\text { development }\end{array}$} & Community involvement & & Access to essential services \\
\hline & $\begin{array}{l}\text { Economics, social and cultural } \\
\text { rights }\end{array}$ & & Education and culture & & Education and awareness \\
\hline & $\begin{array}{l}\text { Fundamental principles and } \\
\text { rights at work }\end{array}$ & & $\begin{array}{l}\text { Employment creation and skills } \\
\text { development }\end{array}$ & \multirow[t]{6}{*}{$\begin{array}{l}\text { The } \\
\text { environment }\end{array}$} & Prevention of pollution \\
\hline \multirow[t]{5}{*}{$\begin{array}{l}\text { Labour } \\
\text { practices }\end{array}$} & $\begin{array}{l}\text { Employee and employment } \\
\text { relationships }\end{array}$ & & $\begin{array}{l}\text { Technological development and } \\
\text { access }\end{array}$ & & sustainable resource use \\
\hline & $\begin{array}{l}\text { Conditions of work and social } \\
\text { protection }\end{array}$ & & Wealth and income creation & & $\begin{array}{l}\text { Climate change mitigation and } \\
\text { adaptation }\end{array}$ \\
\hline & Social dialogue & & Health and safety at work & & $\begin{array}{l}\text { Protection of the environment, } \\
\text { biodiversity and restoration of } \\
\text { natural habitats }\end{array}$ \\
\hline & Health and safety at work & & \multirow[t]{2}{*}{ Social investment } & & \\
\hline & $\begin{array}{l}\text { Human development and training } \\
\text { in the workplace }\end{array}$ & & & & \\
\hline
\end{tabular}

\section{Case study value to society}

Social value of the business model was mainly found to relate to the following categories of Table 3: employment creation (social); Wealth and income creation (wider economic); social investment (social); prevention of pollution and sustainable resource use (environment) which helps avoid environmental life cycle impacts discussed in Appendix $\mathrm{C}$ when looking at economy wide effects.

The low carbon energy network results in investment that creates employment (societal value); investment also brings financial value into the community and council customers (exchange value); cleaner energy $\sim 85 \%$ of heat and $\sim 70 \%$ of power now comes from CHP in the case study area which is resulting in $\mathrm{UK}$ and local $\mathrm{CO}_{2}$ and energy independence policy implementation (social investment and social and environmental use value) without increasing council tax and energy bills (societal exchange value). The Council also receives more interest 
than $£$ value paid in loans to E Company which can be used for further social investment in future.

The company also generates some indirect dis-value (social and environmental) because of their enacted business model, including gas use, emission of GHG and other local polluting gases. The energy production process mix is currently inherently polluting, though the processes employed by ECompany pollute at levels lower than conventional energy generation. The resource through put in terms of annual gas use by ECompany (their main material input) in the council area is $\sim 14,473 \mathrm{MWh}$. In terms of $\mathrm{CO}_{2}$ emissions, their district energy system produces electricity at $0.337 \mathrm{kgCO}_{2} / \mathrm{kWh}$ and heating at: $0.231 \mathrm{kgCO}_{2} / \mathrm{kWh}$. Beyond these material throughputs and emissions, there will also be some additional social and environmental impacts associated with the gas inputs they use. There is pollution from oil and gas extraction (environmental dis-value) and potential for accidents associated with gas extraction (social dis-value).

It was not viable within the resource constraints of the project to undertake a full life cycle analysis of all environmental impacts but through application of the framework we have identified the main direct social and environmental impacts for society and the natural environment. Companies that apply the framework themselves and have the resources and access to data should ideally make use of one or both of the life cycle approaches that we have laid out and identified in Appendix $\mathrm{C}$ to fully explore.

\subsubsection{Use of a value proposition in context}

Context is integral to exploring value creation, value capture, viability of a business model and dis-value of consumption and production, as these are all shaped by location, time, context and surrounding systems; the category is therefore pertinent to how the business model creates 35 
value for the individual, organisation and society. None of the previous frameworks have use of a value proposition in context as a category. Upward and Jones (2016) have context in the background of their framework but it needs to be explicitly up front in the foreground and focused on value, as regulatory, policy and physical (and other) contexts can have huge effect on value creation and capture as demonstrated by the case study in this paper.

The value category was developed based on a discourse on value from Service Dominant Logic (Vargo and Lusch, 2008) as well as other literature. The initial premise is that value is cocreated (Parry and Tasker, 2014; Chandler and Vargo, 2011) in the use of a value proposition within a situated context, such that value is shaped by the system around it (Vargo and Lusch, 2008; O'Cass and Ngo, 2011; Ng et al. 2013). There is a need to capture use context explicitly during interviewees, and examine if providers have visibility and evidence of customer practice linked to their offering. Viability of a value proposition is determined by context and practice knowledge, which may create barriers to sustainable business models (Ceschin, 2014). The value of an offer in context may differ considerably, not just because of the context, but because of knowledge and practice of the actors and the synergy and interaction of various parts of a system. Dis-value, also is shaped by the context and system e.g. from emissions to sensitive environments and ecosystems etc.

To elucidate value questions to be asked include: 'What are the different contexts in which the customer uses your offer?', 'How does context effect the value proposition?', 'Do key resources change with context?', 'Given different contexts, how does the value of the proposition change from the customer's perspective?', 'Where is your production conducted (if relevant)? - e.g. in environmentally sensitive areas, or areas where there are water conflicts?' 


\section{Case study use of a value proposition in context example}

Interviews identified that there is a national legal context and local policy context relating to climate change and $\mathrm{CO}_{2}$ emissions reduction (UK Climate Change Act 2008 etc.) that has meant that GHG reduction is important and has value. ECompany cite the UK governments CHP policy as shaping their context and the exchange value they can create resulting from ECompany's favourable CHP offer. The local Council's Climate Change Strategy which seeks to achieve both reductions in carbon emissions and improved energy independence is critical as this drives policy objectives (and use value) that the Council seeks ECompany to address. Mr James stated: "The overriding benefit is that the Council can deliver on both statutory and non-statutory policies in a cost-efficient manner". He also stated "the principal policy context for this is the Council's Climate Change Strategy which seeks to achieve both reductions in carbon emissions and improved energy independence". A potential indication of the extent of use value of this is reflected in their payment to ECompany as Mr James stated that the "main revenue is the Council". Being in a democracy is a key context that motivates the Council and the business model's emergence and functioning, as the need to be re-elected does not exist otherwise - rendering perceived value of Councillors' performance (to the public) redundant. The context of the operation of the electricity system is also important to how ECompany creates monetary value from demand response energy services they can provide. Benefits from demand side response fall across actors in the supply chain (see Bradley et al 2013); ECompany configure the business model to be vertically integrated to realise these, a key characteristic of the business models functioning.

The favourable environmental policy context that ECompany delivers for the Council creates an incentive for firms that seek low carbon emission power to site themselves in the area. The 
arrival of these new businesses creates further economic benefits for the community. As $\mathrm{Mr}$ James put it "the Council area as a business community is attracting businesses into the area and investment in the town centre. Companies can benefit from the lower $\mathrm{CO}_{2}$ network." The Council also gains voter recognition of low-cost policy implementation that does not impact on council tax. Mr James also stated: "If you assume that $14 \%$ of consumers are proenvironmental, then $14 \%$ gain benefit from what we do". It is clear that without the current political, policy and energy systems that this business model would not have a motivation or be viable and therefore the emergence of the business model, and the social and environmental value it delivers is therefore highly dependent on the political, policy and energy systems in place that encourage its emergence.

\section{Conclusion and Policy Implications}

Business models are key in determining an organisations strategic direction and sustainable development (Schaltegger et al. 2011). Following a review of the sustainable business model frameworks in the sustainable business model literature (Schaltegger et al. 2011; Bocken et al. 2013 \& 2014; Geissdoerfer et al. 2016 and 2016a; Joyce and Paquin 2016; Lüdeke-Freund 2013; Morioka et al. 2016; Upward and Jones 2016; Witjes and Lozano 2016; Kurucz et al. 2017 and others in Table 1) weaknesses were identified in business model frameworks employed in terms of applicability for the current study. Specifically, these include the conceptualisation and definition of value, a lack of clarity over definition and what sustainability means and gaps in systematic and strategic assessment of social and environmental impacts and goals as well as ability to enable in-depth case study analysis. A business model framework based upon extending the business model canvas (Osterwalder and 
Pigneur, 2010) is developed to address these gaps as set out in the paper. The resultant business model is applied in an in-depth case study with an energy provider.

There are many significant monetary and non-monetary benefits from investment of time in the use of business models as strategic tools. From application of the business model framework of this study an in depth understanding of the business model, its functioning, how it creates and captures different types of value and for whom was documented, as well as its contribution to sustainable development. As seen in section 4, the framework allowed us to critically and systematically examine the energy business model in terms of its economic, social and environmental sustainability. The in depth case study can now be learnt from by others. The framework is of substantial value to both practitioners and policy makers in aiding decisions about how and why they might engage with (and improve environments for) such business models and which are most beneficial to society and the environment. The framework could can be applied for in depth comparative analysis of different business models to compare their credentials and help government and policy decide which types of sustainable business models they might like incentivise, or directly engage with if there is a clear benefit in cost effective delivering sustainability policy. In this sense, the framework provides a tool to business, government and academics that they can now apply to further develop their own in depth case studies, and thus helping systematically document and build in depth case study analysis lacking in the literature. This is an important contribution.

With regards to examination of the limitations of the framework, articulation of the business model relies upon a strong engagement from respondents in interview, so the extent to which one gains an in depth understanding of the business model, does rely upon a strong engagement by respondents. Documentation on such things as profitability and sustainability can however 
enable a fuller analysis as can an ongoing correspondence with the organisation. Secondly, it is difficult/impossible to determine quantitatively all value generated by the firm in the same units, to determine comprehensively whether it is value maximising. One might then ask what is the point in having the goal of looking at the extent to which an organisation is value maximising? Based on the case study this paper concludes that it is still a useful assumption from which to assess an energy business model in terms of its sustainable development, as one can still observe much of the value quantitatively and where it is going to (i.e. individuals or society). Second, it is very useful to systematically scope out all the different types and sources/targets of value creation using the individual/organisation/society (Lepak et al. 2007) and environment approach outlined here, as it helps understand business model functioning, and types of value created and its distribution. This leaves the analyst in a much stronger position to assert whether the business model is value maximising for society or profit maximising for individuals or organisations. Without this organisations could claim to have a highly sustainable energy business model, when actually it is not aligned with the $1^{\text {st }}$ (or other two) aims of sustainable development. Such a situation would not support sustainability in line with the Brundtland definition (WCED 1987) of sustainable development and its aims.

\section{Acknowledgments}

I wish to thank all participants that have engaged with the research, anonymous reviewers and the University of the West of England for their funding of the SPUR 6 Early Career Researcher Grant: 'Understanding and assessing business models for sustainability'. I also thank Nicola Horner for her reading of the final version of this document.

\section{References}


Allwood, M. F., Ashby, T. G., Gutowski, Worrell E., 2011. Material Efficiency: a White Paper. Resources, Conservation and Recycling. 55, 362, 362-381.

Zott, C. \& Amit, R. 2010. Business Model Design: An Activity System Perspective. Long Range Planning, 43, 2, 216-226.

Sen A., 1999. Development as freedom. New York: Oxford University Press.

Baden-Fuller, C., and Haefliger S., 2013. Business models and technological innovation. Long Range Planning. 46, 6, 419-426.

Baden-Fuller, C., Mangematin V., 2013. Business models: A challenging agenda. Strategic Organization, 11, 418-427.

Baden-Fuller, C. \& Morgan, M.S. 2010. Business Models as Models. Long Range Planning, 43, 2, 156-171.

Bradley, P. , Leach, M. and Torriti, J. 2013. A review of the costs and benefits of demand response for electricity in the UK. Energy Policy, 52. pp. 312-327.

British Standards Institution 2008. Publicly Available Specification 2050. Available at: http://www.bsi-global.com/en/Standards-and-Publications/How-we-canhelpyou/Professional-Standards-Service/PAS-2050/ Accessed: 24.04.09.

Beckerman W., 1994. Sustainable Development: Is it a Useful Concept? Environmental Values. 3, 191-209.

Bocken N.M.P., Short S., Rana P., Evans S., 2013. A value mapping tool for sustainable business modelling. Available at: 
https://www.repository.cam.ac.uk/bitstream/handle/1810/245028/A\%20value\%20mapping\% 20tool $\% 20$ for $\% 20$ sustainable $\% 20$ business $\% 20$ modelling.pdf?sequence=1 $\quad$ Accessed: $09 / 3 / 2016$

Bocken N.M.P, Short S.W., Rana P., Evans S., 2014. A literature and practice review to develop sustainable business model archetypes. Journal of Cleaner Production. 65, 42-56.

Ceschin F., 2013. Critical factors for implementing and diffusing sustainable product-Service systems: insights from innovation studies and companies' experiences. Journal of Cleaner Production. $45,74-88$.

Chandler, J. D. and Vargo, S. L. 2011. Contextualization and value-in-context: How context frames exchange. Marketing Theory. 11, 1, 35-49.

Clift R., and Allwood J., 2011. "Rethinking the economy". The Institution of Chemical Engineers, TCE, 837, 30-31.

DesJardins J., 2015. Is it Time to Jump off the Sustainability Bandwagon? Business Ethics Quarterly. $26,1,117-135$.

Evans, S., Vladimirova, D., Holgado, M., Van Fossen, K., Yang, M., Silva, E. A., \& Barlow, C. Y. (2017). Business Model Innovation for Sustainability: Towards a Unified Perspective for Creation of Sustainable Business Models. Business Strategy and the Environment, 26, 597608.

Elkington, J. 1998. Cannibals with Forks: The Triple Bottom Line of 21st Century Business. New Society Publishers, Gabriola Island, Stony Creek. 
França, C. L., Broman, G., Robèrt, K.-H., Basile, G., \& Trygg, L. (2017). An approach to business model innovation and design for strategic sustainable development. Journal of Cleaner Production, 140, 155-166.

Geissdoerfer M., Paulo S., S. Evans, 2016. $14^{\text {th }}$ Global Conference on Sustainable Manufacturing, GCSM 3-5 October 2016, Stellenbosch, South Africa. Procedia Manufacturing, pp. 1-9.

Geissdoerfer M., Bocken N.M.P., Hultink E.J., 2016a. Design thinking to enhance the sustainable business modelling process - A workshop based on a value mapping process. Journal of Cleaner Production. 135, 1218-1232.

ISO 26000 2015. ISO 26000 - Social responsibility. Available at: http://www.iso.org/iso/home/standards/iso26000.htm Accessed: 10/03/2016

Joyce, A., Paquin, R., 2016. The triple layered business model canvas: A tool to design more sustainable business models. Journal of Cleaner Production. 135, 1474-1486.

Kleining, G., 1998. Das Rezeptive Interview. Bielefeld: University of Bielefeld.

Knorr Cetina, K., 2001. Objectual Practice, in Schatzki, T.R., Knorr Cetina, K. \& von Savigny, E. (eds). The practice turn in contemporary theory. pp 175-188, London: Routledge

Kurucz E., Colbert B.A., Lüdeke-Freund F., Upward A., Willard B., 2017. Relational leadership for strategic sustainability: practices and capabilities to advance the design and assessment of sustainable business models. Journal of Cleaner Production. 140, 189-204.

Krutilla, J.V., 1967. Conservation reconsidered. American Economic Review 57, 787-796.

Lele S., 1991. Sustainable development: a critical review. World Development. 19, 607 -621. 
Lepak D, Smith KG, Taylor MS. 2007. Value creation and value capture: A multilevel perspective. Academy of Management Review, 32, 1, 180 - 194.

Lüdeke-Freund, F. 2013. Business Models for Sustainable Innovation: Conceptual Foundations and the Case of Solar Energy. Dissertation. Available at: https://d-nb.info/1047482576/34 Accessed: 09/03/2016.

Lüdeke-Freund, F., Carroux, S., Joyce, A., Massa, L., \& Breuer, H. 2018. The sustainable business model pattern taxonomy-45 patterns to support sustainability-oriented business model innovation. Sustainable Production and Consumption, 15, 145-162.

Mebratu D., 1998. Sustainability and sustainable development: historical and conceptual review. Environmental Impact Assessment Review 18, 493-520.

Morioka SN, Evans S., Monteiro de Carvalho M., 2016. Sustainable business model innovation: exploring evidences in sustainability reporting. $13^{\text {th }}$ Global Conference on Sustainable Manufacturing - Decoupling Growth from Resource Use. Procedia CIRP 40, 569 -667.

Morioka, S.N., Bolis, I., \& Carvalho, M. M. D. 2018. From an ideal dream towards reality analysis: Proposing Sustainable Value Exchange Matrix (SVEM) from systematic literature review on sustainable business models and face validation. Journal of Cleaner Production, 178, 76-88.

Morioka, S. N., Bolis, I., Evans, S., \& Carvalho, M. M. 2017. Transforming sustainability challenges into competitive advantage: Multiple case studies kaleidoscope converging into sustainable business models. Journal of Cleaner Production, 167, 723-738.

Natural Capital Committee 2013. The State of Natural Capital: Towards a framework for measurement and valuation. A report from the Natural Capital Committee. Available at: 44 
http://www.environmentbank.com/files/state-of-natural-capital-report-2013-1.pdf Accessed: $10 / 03 / 2016$

Natural Capital Committee 2015. The State of Natural Capital Protecting and Improving Natural Capital for Prosperity and Wellbeing. Available at: https://www.cbd.int/financial/values/ukstateof-naturalcapital.pdf Accessed: 10/03/2016

Ng, I.C.L., 2012. Value and Worth; creating new markets in the digital economy, Cambridge: Innovorsa Press.

Ng, I.C.L., Ding, D.X., Yip, N., 2013. Outcome-based Contracts as New Business Model: The Role of Partnership and Value-driven Relational Assets. Industrial Marketing Management. 42, 730743.

Ng, I.C.L., Smith, L.A. 2012. An Integrative Framework of Value, in: Stephen L. Vargo, Robert F. Lusch, in (Eds.), Special Issue - Toward a Better Understanding of the Role of Value in Markets and Marketing. Review of Marketing Research. 9, 207 - 243.

O'Cass, A., Ngo L.V., 2011. Examining the firm's value creation process: a managerial perspective of the firm's value offering strategy and performance. British Journal of Management. 22, 646671.

Osterwalder A, and Pigneur Y., 2010. Business Model Generation - A Handbook for Visionaries, Game Changers and Challengers. John Wiley and Sons, Inc., Hoboken, New Jersey.

Osterwalder, A., Pigneur, Y., Bernarda, G., Smith, A., 2014. Value Proposition Design: How to Create Products and Services Customers Want. John Wiley and Sons, Inc., Hoboken, New Jersey. 
Parry, G.,Tasker P., 2014. Value and servitization; creating complex deployed responsive services? Strategic Change. 23, 303-315.

Pater L.R., Cristea S.L., 2016. Systemic Definitions of Sustainability, Durability and Longevity. Social and Behavioural Sciences. 221, $362-371$.

Perman R.,Ma Y., McGilvray J., Common M. 2011. Natural Resource and Evironmental Economics. Third Edition. Pearson Education Ltd, Essex.

Pezzoli, K., 1997. Sustainable development: a transdisciplinary overview of the literature. Journal of Environmental Planning and Management. 40, 5, 549-574.

Plottu E., Plottu B., 2007. The concept of Total Economic Value of environment: A reconsideration within a hierarchical rationality. Ecological Economics 61, 52-61.

Reason, P., Bradbury, H., 2001. Inquiry and Participation in Search of a World Worthy of Human Aspiration, in: Reason P., Bradbury H., (Eds.), Handbook of Action Research: Participative inquiry and practice. London: Sage Publications, pp. 1-14.

Robinson, J., Tinker J., 1997. Reconciling ecological, economic, and social imperatives: a new conceptual framework. In: Schrecker, T. (Ed.), Surviving Globalism: Social and Environmental Dimensions. Macmillan, St. Martin’s Press, London, New York, pp. 71-94.

Rockström J., Steffen W., Noone K., Persson A., Chapin F.S., Lambin E.F., Lenton T.M., Scheffer M., Folke C., Schellnhuber H.J., Nykvist B., De Wit C.A., Hughes T., Van der Leeuw V., Rodhe H., Sörlin S., Snyder P.K., Costanza R., Svedin U., Falkenmark M., Karlberg L., Corell R.W., Fabry V.J., Hansen J., Walker B., Liverman D., Richardson K., Crutzen P., Foley J.A., 2009. A safe operating space for humanity. Nature. 461, 472-475. 
Schaltegger S., Lüdeke-Freund F., Hansen E.G., 2011. Business Cases for Sustainability and the Role of Business Model Innovation Developing a Conceptual Framework. Available at: https://www2.leuphana.de/umanagement/csm/content/nama/downloads/download_publikatio nen/Schaltegger_Luedeke_Freund_Hansen_Business_Case_Sustainability.pdf Accessed: $09 / 03 / 2016$

Senn A., (1999). Development as Freedom. Oxford University Press. Oxford.

Seyfang G., Park J.J., Smith A. 2013. A thousand flowers blooming? An examination of community energy in the UK. Energy Policy, 61, 977-989.

Sneddon C., Howarth R.B., Norgaard R.B., 2006. Sustainable development in a post-Brundtland world. Ecological Economics. 57, 253 - 268.

Steffen W., Richardson K., Rockström J., Cornell S,E., Fetzer I., Bennett E.M.,, Biggs R., Carpenter S.R., De Vries W., De Wit A.c., Folke c., Gerten D., Heinke J., Mace G.M., Persson L.M., Ramanathan V., Reyers B., Sörlin S. 2015. Planetary boundaries: Guiding human development on a changing planet. Science, 347, 622, p. 736-747.

Teece, D.J. 2010. Business models, business strategy and innovation. Long Range Planning. 43, 2/3, 172-94.

UK Climate Change Act 2008. Available at: http://www.legislation.gov.uk/ukpga/2008/27/contents Accessed: 11/10/19

Upward A., and Jones P., 2016. An ontology for strongly sustainable business models: Defining an enterprise framework compatible with natural and social science. Organization and Environment. 29, 1, 97-123. 
Vargo, S.L., Lusch R., 2008. Service-dominant logic: continuing the evolution. Journal of the Academy of Marketing Science. 36, 1, 1-10.

WCED (World Commission on Environment and Development) 1987. Our Common Future. Oxford University Press, Oxford. Available at: http://www.un-documents.net/our-common-future.pdf Accessed: 29.10 .13

Weisbrod, B.A. 1964. Collective consumption of individual-consumption goods. Quarterly Journal of Economics. 78, 471-477.

Webber, D. J., Webber, G. A., Berger, S., \& Bradley, P. 2018. Explaining productivity in a poor productivity region. Environment and Planning A, 50, 1, 157-174.

Witjes S., Lozano R., 2016. Towards a more circular Economy: Proposing a framework linking sustainable public procurement and sustainable business models. Resources, Conservation and Recycling. 112, 37-44.

Yang, M., Vladimirova, D., \& Evans, S. 2017. Creating and capturing value through sustainability: The Sustainable Value Analysis Tool. Research Technology Management, 60, 3, 30-39.

Yin, R. K. 2009. Case study research: Design and methods (4th Ed.). Thousand Oaks, CA: Sage.

\section{Appendix A}

Your goal is to:

1 Select a service offering: for your practice example summarise the salient aspects of the value proposition, realisation in use and capture mechanism (make use of the business model canvas to help you in this task).

2 Identify the different types of material inputs (and onsite emissions) that occur in the provision of the good or service (and its use) and the magnitude each flow? 


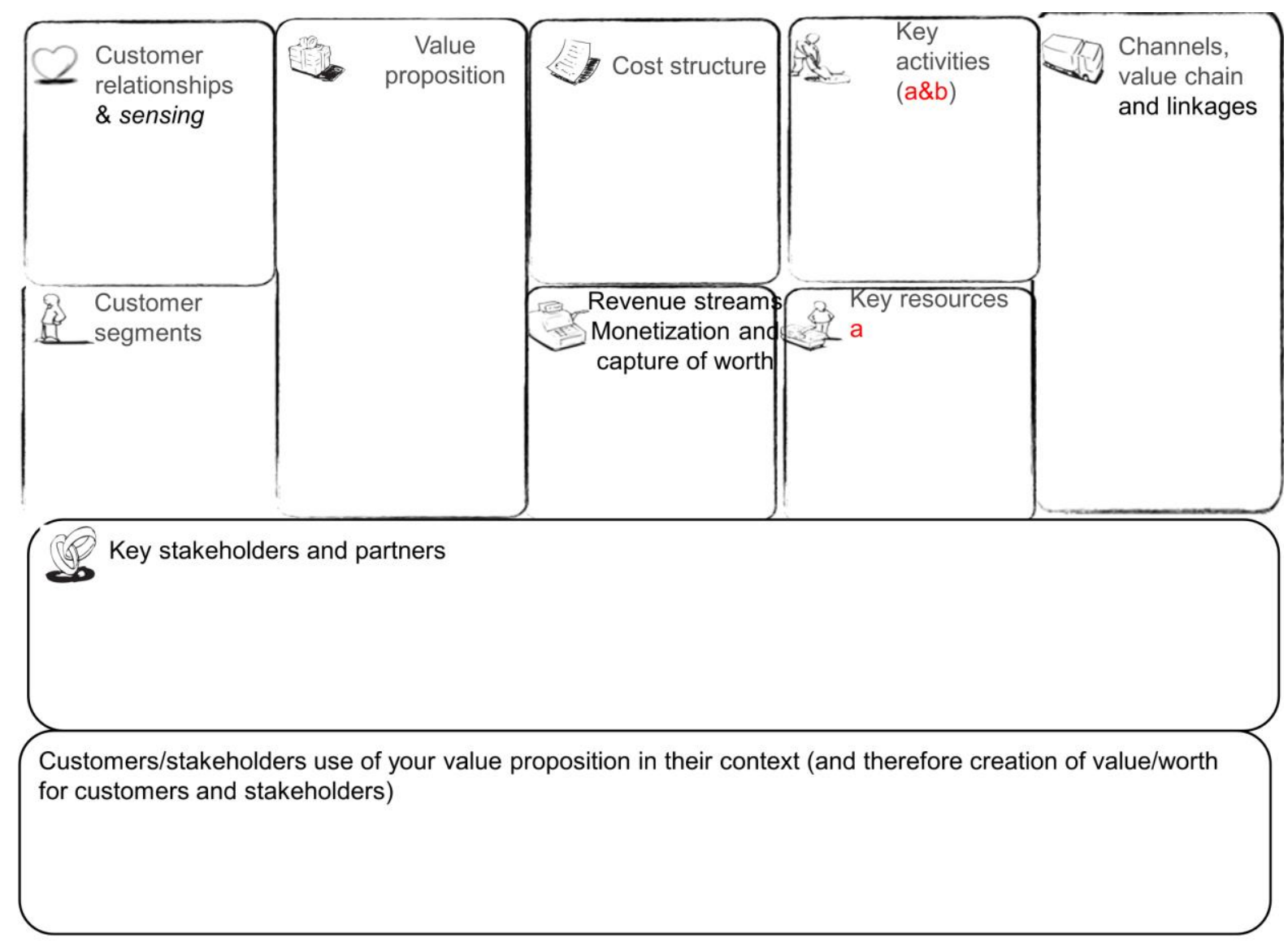




\section{Appendix B: Summary results from the workshop exercise analysed by each category}

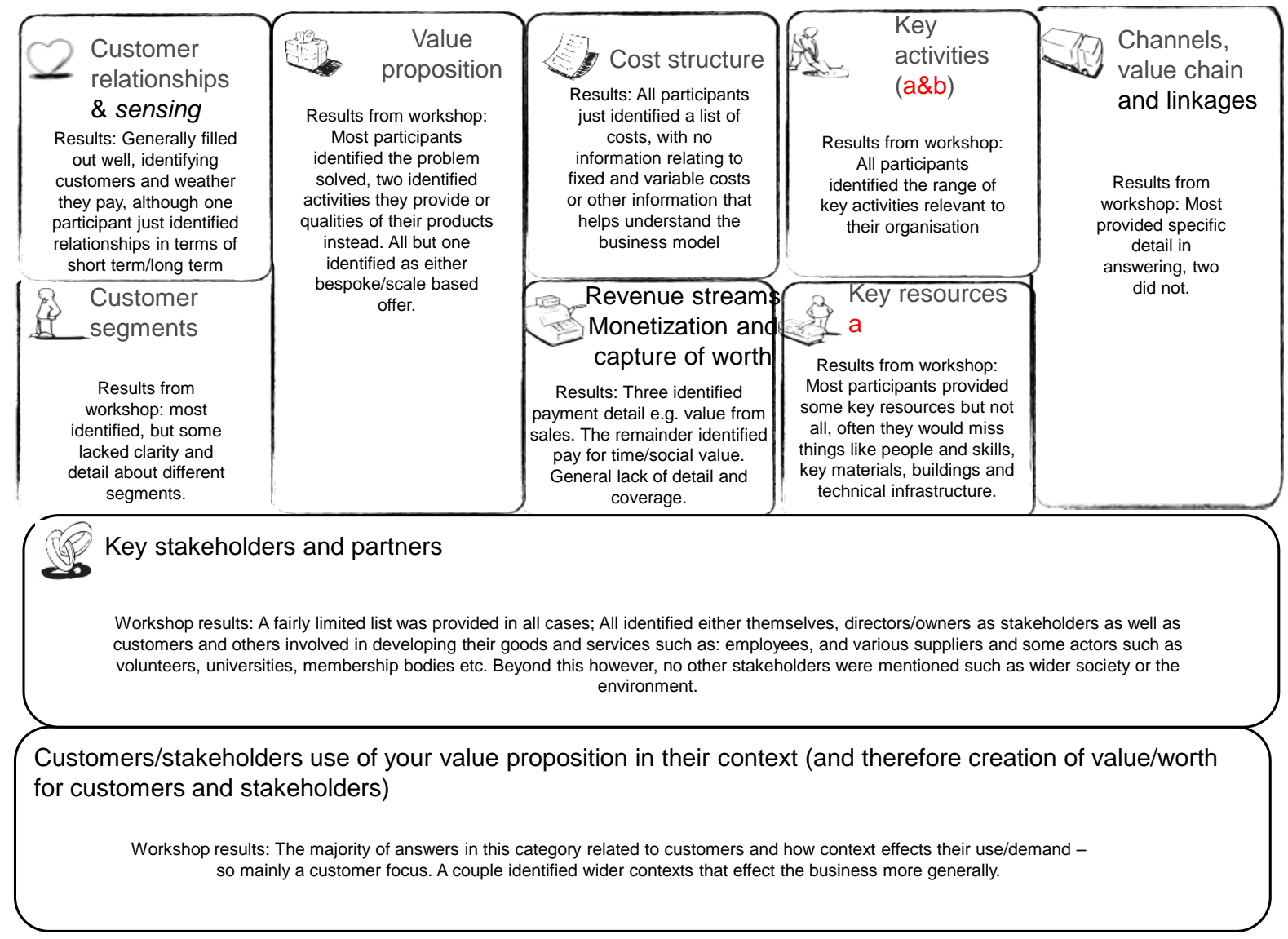

\section{Improvements made after the workshop:}

After the workshop substantial improvements were made mainly though providing detailed questions for each category to better guide participants to elucidate the full detail required for each category and in esnuring better conceptualisation and understanding of value. Please see the final framework in section 4.

\section{Appendix C}

\section{Environmental value/dis-value}

In assessing environmental value/disvalue generated, one should examine: 
- Key resources predominantly used when applying the current business model. The business model affects material flows through firms, and a change in business model affects such flows (therefore helping address the first aim of sustainable development).

- Direct generation of emissions, particularly for key global environmental pressures such as $\mathrm{CO}_{2}$ and greenhouse gases (GHG).

- Some industries such as heavy manufacturing, may also emit many other emissions and managers can extract data on these from their ISO 14000 environmental management systems or similar environmental management systems. Direct chemical use and releases should also be included.

- A method of assessing natural capital owned by organisations is provided below should this be relevant.

\section{Accounting for the organisations effects on Natural capital}

- Natural capital can be defined as: "the elements of nature that produce value or benefits to people (directly and indirectly), such as the stock of forests, rivers, land, minerals and oceans, as well as the natural processes and functions that underpin their operation.” (Natural Capital Committee 2013, p.10). This can include such things as provisioning services (agriculture and farming for food etc.); regulating services (water purification, flood defence); cultural services, (heritage recreation, aesthetics) supporting services (biodiversity, soil function). The last category may not feature in the accounts to avoid double counting.

- The UK governments Natural Capital Committee (Natural Capital Committee 2015) have developed a corporate natural capital accounting (CNCA) framework that firms can apply at the micro company/organisation level. The corporate natural accounting framework allows one to understand how a particular firm's current activities are effecting the natural capital that it is responsible for and is available for free for application from Natural Capital Committee 2015). 
- Following the guidelines should result in a natural capital balance sheet like the example below. Economy wide natural capital impacts from the inputs that a firm buys are more likely to be accounted for in market prices, but an indicator of the extent of use of such resources is indicated but the extent of material inputs used its production and provision.

\section{Life cycle environmental impacts}

In line with the aims of sustainable development, wider ecological integrity can be pursued by looking at the scale of key physical resource flows and their indirect (economy wide) impacts, as it is the scale of these flows that drives life cycle environmental impacts elsewhere in the economy (Allwood et al. 2011). Two approaches for this assessment are set out below.

1.) Indirect water use, emissions and land use are embodied in inputs/resources brought into a company for its production can be estimated as follows: One way to understand how a business model influences these, would be to measures the key direct material inputs purchased and do a scoping analysis using an economy wide environmental input-output model to estimate the indirect physical impacts associated with the value spent on the key materials/resources used by the industry. See tools such as: http://www.eiolca.net/ There are limitations with such environmental input output approaches as the models are often quite aggregated by sector and product.

2.) A more detailed approach is to apply consequential process life cycle analysis where one looks in detail at the environmental impacts of all the core parts of a supply chain using approaches such as process based life cycle analysis. A third alternative is one can apply hybrid environmental input-output life cycle analysis which conducts process based LCA for just certain parts and then input-output based LCA for the remainder to reduce expense of the process based LCA. 